\title{
Magnús Eiríksson og Grundtvig
}

\author{
Carl Henrik Koch
}

I det 19. århundredes Danmark optrådte tre reformatorer: Grundtvig, Kierkegaard og den dansk-islandske teolog Magnús Eiríksson (1806-81), hvoraf den sidste var den mest radikale. De to første fik som bekendt stor betydning for det religiøse liv i landet i sidste halvdel af det 19. og første halvdel af det 20. århundrede. Den sidste blev hurtigt glemt. Selv mente han, at han blev tiet ihjel. Han kritiserede skarpt de to andre, som aldrig værdigede ham et gensvar. Men først og fremmest kritiserede han tidens mest fejrede danske systematiske teolog, Hans Lassen Martensen, hvis Hegel-inspirerede spekulative teologi han betragtede som et udtryk for, hvad der for Eiríksson var et frafald fra den sande kristendom, der for ham var en forening af en from og enfoldig gudstro og det kristne kærlighedsbud.

I sit relativt omfattende forfatterskab kritiserede Eiríksson i flere omgange Grundtvig. Han opfattede i 1840 'erne Grundtvigs forsvar for baptismen som uvederhæftigt og uærligt, og i 1860'erne angreb han Grundtvigs "mageløse Opdagelse" og teorien om, at Den Apostolske Trosbekendelse stammede fra Jesu egen mund. Som en af tidens få danske tilhængere af den historisk-kritiske Tübingenskole afviste Eiríksson ikke alene Johannesevangeliet som uægte, men forkastede også såvel treenighedsdogmet og læren om Kristi guddommelige natur. Hans skæbne var ikke at blive hørt og ikke at blive taget alvorligt. I nærværende artikel sættes fokus især på hans Grundtvigkritik. ${ }^{1}$

\section{Indledning}

I den lille selvbiografi, der indgår i forordet i det første værk af Magnús Eiríksson, omtaler han sine oplevelser, at han i 1831 kom til København fra

\footnotetext{
${ }^{1}$ En engelsk version af artiklen er udgivet i Magnús Eiriksson. A Forgotten Contemporary of Kierkegaard (Koch 2017a, 167-211).
} 
Island for at studere teologi. Blandt de teologiske retninger var der to, der stod skarpt over for hinanden, nemlig den "evangeliske Retning” anført af teologiprofessoren H.N. Clausen (1793-1877) og "Grundtvigianere" eller de "catholiserende Theologer" med N.F.S. Grundtvig (1783-1872) som den altdominerende hovedskikkelse (Eiríksson 1844, IV og VI).

I 1837 tog Eiríksson teologisk attestats, men fortsatte sine studier og overværede i 1839 en del af de forelæsninger, som den unge og succesombruste universitetslektor Hans Lassen Martensen (1808-84), senere professor i teologi og fra 1854 Sjællands biskop, holdt over tidens teologiske moderetning, den Hegel-inspirerede spekulative teologi. Som de fleste af Martensens unge tilhørere blev også Eiríksson revet med af den veltalende lektor. Mange år senere skrev en anden af hans tilhørere om ordet "speculativ", at

Dette mystiske Ord, der optraadte med det “Absolutes” Klang, glimted gjennem enhver af vor Mesters Kraftsætninger som Solens Blink $i$ et Vandspring. Hvorfra det kom vidste vi ikke, det foer forbi som et Trylleri. Men da det kom til nogen bedre Forstaaelse, viste det sig at være den Kunst med et eklektisk Aggregat af tydske Systemer at kunne bringe Christendommens Mysterier ind under Begrebets Dagslys, saa sikkert, som havde man en Engel sat i Spiritus stillet frem til Analysering (Fibiger 1898, 74).

Også Eiríksson kom sig over sin betagelse og indså det "Grundfalske" (Eiríksson 1844, XI) i Martensens teologi og beskrev i sin første bog den retning, som Martensen stod for, som den "meget farlige, speculerende, uskriftmæssige Retning", som han modstillede "den craskirkelige, katholiserende, grundtvigske” retning (Eiríksson 1844, XIII). Han betragtede begge retninger, men mest den martensenske, som trusler mod den enfoldige, ikke-videnskabeliggjorte kristendom med vægt på kærlighedsbudskabet, som Eiríksson mente var kernen i Kristi forkyndelse.

Baptismen var anledningen til, at Eiríksson trådte frem på den litterære scene. Hans kritik af Martensens og Grundtvigs indslag i diskussioner om baptismen blev en slags indgangsportal til hans senere afvisning af den videnskabelige teologi og af hovedparten af den luthersk-evangeliske teologis traditionelle dogmer. 
Hvis man skal dømme ud fra Grundtvigs efterladte bogsamling, synes han aldrig at have ænset Eiríksson. Her er Eiríksson kun repræsenteret med en enkelt bog (Eiríksson 1849, [Grundtvig 1873], 43, nr. 1290), hvori han kritiserer Martensens hovedværk Den christelige Dogmatik fra 1849. Ingen af de værker, hvori han kritiserede Grundtvig, optræder i auktionskataloget.

Vi ved intet om det personlige forhold mellem Grundtvig og Eiríksson. Så lille, som København og byens intellektuelle overklasse var, kan de dog næppe undgå at have truffet hinanden, og utvivlsomt har Eiríksson overværet nogle af Grundtvigs gudstjenester. Det eneste møde mellem dem, der er registreret, foregik så sent som i 1871 i forbindelse med Det Fjerde Nordiske Kirkemøde i København, hvor Eiríksson fik ordet umiddelbart efter, at Grundtvig havde talt, men blev frataget det igen, da han ikke berørte mødets emne, som var nyrationalismen, og i stedet stillede og kort diskuterede spørgsmålet: "Er den kristelige eller kirkelige Tro, som vi have, det Samme som Kristi Lære og Tro?” Afbrydelsen fik Eiríksson til at bede en bøn om, at Gud ville lede mødets deltagere til sand kristendom. ${ }^{2}$ Han var til sine dages ende en stridsmand for Herren.

\section{Baptismens indtog i Danmark omkring 1840}

I 1839 stiftedes i København den første baptistiske menighed. Sektens indtrængen i Danmark vakte straks de kirkelige og de statslige myndigheders opmærksomhed. Til forskel fra den evangelisk-lutherske tro, som var fastlagt i Den Augsburgske Bekendelse fra 1530, afviste baptisterne barnedåben og praktiserede i stedet voksendåb, de administrerede nadveren på en anden måde end den danske statskirke, og håndhævelse af kirketugten var for baptisterne et anliggende for menigheden og ikke, som i den danske statskirke, præsternes opgave.

${ }^{2}$ Forhandlinger paa Det Fjerde Nordiske Kirkemøde i Kjøbenhavn Den 5., 6. og 7. September 1871, 46-51. 
Især afvisningen af barnedåben, som var begrundet $\mathrm{i}$, at der tilsyneladende mangler belæg for den i Det Nye Testamente, ${ }^{3}$ vakte opsigt og var også i strid med lovgrundlaget for den danske stat. Af Kongeloven fra 1665 fremgik det, at det var kongemagtens opgave at håndhæve Den Augsburgske Bekendelse og de deri indeholdte dogmatiske bestemmelser "og ved samme reene og uforfalskede Christelige Troe holde Landsens Jndbyggere og den vældeligen haandhæffve og beskierme i disse Lande og Riger mod alle Kiettere, Sværmere og Guds bespottere" (Himmelstrup \& Møller 1970, 16). I bekendelsesskriftets niende artikel siges om de evangeliske menigheders lære om dåben, "at den er nødvendig til frelse, og at Guds nåde tilbydes ved dåben, og at børn bør døbes, idet de, når de ved dåben er overgivet til Gud, tages til nåde af ham”. Desuden fordømmes gendøberne eller blot døberne, som hævdede, at den personlige tro var en forudsætning for dåben, og derfor forkastede barnedåben (Langhoff 1980, 26). I artiklen hævdes således dåbens nødvendighed og barnedåbens retmæssighed. I Christian 5.s danske lov fastlægges supplerende, at foruden Bibelen og Den Augsburgske Bekendelse hører også de tre oldkirkelige symboler (Den Apostolske, Den Nikænske og Den Athanasianske Trosbekendelse) og Luthers Lille Katekismus til den danske kirkes bekendelsesskrifter. Specielt fastslås det i 2-5-5, at hvis børn ikke er døbt senest otte dage efter fødslen, idømmes forældrene en bøde. ${ }^{4}$ I dåbsforordningen af $1828 \mathrm{blev}$ dette præciseret. Muligheden for i levende live at udtræde af statskirken eller stå udenfor var således udelukket. ${ }^{5}$

3 Sagen var omstridt. F.eks. havde tidens store tyske teolog Friedrich Schleiermacher, som de førende danske teologer H.N. Clausen og H.L. Martensen var påvirket af, i sit dogmatiske hovedværk Der christliche Glaube nach den Grundsätzen der evangelischen Kirche im Zusammenhange dargestellt skrevet: "[...]. Daher hätte man sehr füglich, um der Einsezung Christi wieder näher zu treten, bei der Reformation die Kindertaufe fahren lassen können, und wir könnten es noch jezt thun, ohne da $\beta$ wir uns deshalb losgesagt hätten von der Gemeinschaft mit derjenigen Periode, in der es nur Kindertaufe gab, wenn wir nur nicht die Kindertaufe für ungültig erklären." (1831, bd. 2, 423 (\$138)).

4 Kong Christian den Femtis danske Lov (1929).

5 Den danske statskirkes retsgrundlag blev kortlagt i 1842 af den unge D.G. Monrad i en endnu læseværdig artikel "Om Retten til at udtræde af Statskirken (I Anledning af Baptisterne)" i det fjerde af hans Flyvende politiske Blade (Monrad 1842). 
Både de kirkelige og de verdslige myndigheder - som udgjorde en enhed - var i vildrede med, hvordan man skulle behandle de erklærede baptister. Der var ikke enighed i bispekollegiet, og sagen blev forelagt Danske Kancelli, der udbad sig en udtalelse hos den danske kirkes primas, Sjællands biskop siden 1834, Jacob Peter Mynster (1775-1854).

Allerede tidligt i forløbet havde Mynster gjort sin stilling klar. I en tale, som han holdt d. 30. marts $1842 \mathrm{i}$ anledning af ordination af en præst, der skulle udsendes til Grønland, havde han med udgangspunkt i Johannesevangeliets Jesusord: "Og jeg haver andre Faar, som ikke ere af denne Sti: dem bør det mig og at føre did, og de skulle høre min Røst; og der skal blive een Hjord, een Hyrde" (Joh 10,16) ${ }^{6}$, beklaget den strid, der var opstået inden for kirken, og at kirkens dåb endog var draget i tvivl. Imidlertid måtte landets øvrighed have pligt til at opretholde kirkens enhed og derfor at "haandhæve den christelige Tro iblandt Folket, og turde den give Folket til Priis for alle Vildfarelser?” (Mynster 1842, 12). Mynster måtte på denne baggrund være tilhænger af, at baptisternes børn blev tvangsdøbt mod forældrenes vilje, og den kongelige resolution af 23. december 1842 afgjorde sagen. Baptisternes børn skulle døbes, og hvis forældrene undlod at føre dem til dåben, skulle de idømmes bøde og eventuelt fængselsstraf, og børnene skulle tvangsdøbes. Baggrunden for Mynsters holdning til baptismen var ikke mindst hans frygt for, at den enhed mellem stat og kirke, som var lovfæstet i Kongeloven, skulle gå i opløsning.

Men i præstestanden var der stærke forbehold over for med loven $i$ hånd at gennemtvinge noget, der egentlig var et samvittighedsanliggende. Søren Kierkegaards bror, Peter Christian Kierkegaard (1805-88), der var præst i Pedersborg nær Sorø, nægtede af samvittighedsgrunde at døbe de børn af baptistiske forældre, der ved politiets hjælp blev bragt til hans kirke. Også andre fulgte trop. I 1849 knæsattes i Junigrundlovens $\$ 81$ (i dag $\$ 67)$ religionsfriheden i Danmark med ordene: "Borgerne have Ret til at forene sig i Samfund for at dyrke Gud paa den Maade, der stemmer med deres Overbevisning (...)." (Himmelstrup \& Møller, 1970). Allerede den 6. juni 1848 var ved kongelig resolution alle sager mod baptisterne ophævet. Igennem hele perioden fra 1842 til 1848 havde administrationen af

${ }^{6}$ Her og i det følgende citeres efter den autoriserede Bibeloversættelse af $1819 \mathrm{i}$ Biblia, det er: den ganske Hellige Skrifts Bøger (1825). 
1842-resolutionen været vaklende. Beklagende skrev Mynster i den del af sine erindringer, der er dateret 1846 :

Ved Forhandlingerne i Statsraadet havde Kongen (Christian 8) ivrigen staaet paa, at Baptisternes Børn skulde døbes, skiøndt hans Motiver ikke vare ganske de samme, som mine. Jeg for min Deel kan ikke forlade den Overbeviisning, at Staten er berettiget til at fordre, at ethvert Barn strax skal henregnes til et af den anerkiendt Religionssamfund, og at derfor, da Baptisterne udtrykkeligt erklære, at deres Børn ikke høre til deres Samfund, førend de som Voxne selv kunne erklære sig, saa maa vor Kirke antage sig dem, som andre forladte Børn (Mynster 1854, 273).

Efter at have omtalt P.C. Kierkegaards og andres vægring mod at følge resolutionens påbud fortsatte Mynster:

Jeg foreholdt i denne Anledning Kongen, at det var mig umueligt at skaffe Anordningerne overholdte, dersom jeg ikke fik Soutien [støtte]. Dette tilsagde Kongen mig, havde ogsaa en heftig Samtale med en af de ommeldte Præster, der kom til ham, men endte dog med, at han vilde tage Sagen under nærmere Overveielse; Cancelliet gav en vaklende Forestilling og dermed er Sagen blevet liggende, saa at Enhver giør, hvad han vil (Mynster 1854, 273).

Myndighedernes fremfærd mod baptisterne fremkaldte adskillige polemiske indlæg, hvoraf de vigtigste var forfattet af N.F.S. Grundtvig samt biskop over Fyns Stift Nicolai Faber (1787-1848), H.L. Martensen, filosoffen Hans Brøchner (1820-75) og sidst, men ikke mindst Magnús Eiríksson, hvis indlæg var langt det største, over 700 sider. Alle de fire første bidrag til diskussionen blev omtalt af Eiríksson og for Grundtvigs, Martensens og Fabers vedkommende kritiseret. I det følgende skal kun Eiríkssons kritik af Grundtvigs opfattelse gøres til genstand for nærmere omtale, hvorimod Fabers, Martensens og Brøchners indlæg i diskussionen kun indledningsvist vil blive kortfattet berørt. ${ }^{7}$

7 H.N. Clausen og D.G. Monrad bidrog også til diskussionerne om baptismen, men da deres bidrag udkom efter Eiríkssons, inddrages de ikke her. 
Over for baptisternes påstand om, at dåben forudsætter tro, hævdede Martensen, at "Troen kommer af Daaben" (Martensen 1843, 12). Dåbens mysterium er, at dåbsbarnet er genstand for Kristi udvælgelse, "idet han, som Kirkens Hoved, sætter sig selv i organisk Forhold til Individet, og derved skjænker det Kilden til al Troesudvikling, al Christelig Begeistring og Produktivitet" (Martensen 1843, 13). Brøchner kritiserede Martensens forsøg på at forstå dåbsdogmet og beskrev ironisk reformationstidens "Dogmatikere" som "Mænd med et beundringsværdigt Mod og en Resignation paa al Fornuft, der maa vække vor Forbauselse og aftvinge os den samme Agtelse, som vi maae føle for de indiske Fakirer. Der var ikke vor Tids Theologies sørgelige Halvhed og Feighed (...)" (Brøchner 1843, 19). Faber tilskrev barnet en medfødt fornuftig sjæl, som "er istand til at modtage Indtryk baade fra den Udenverden i Almindelighed som fra andre Mennesker i Særdeleshed og gjennem de høiere Evner fra Gud selv. Herved fremkaldes en Virksomhed i Barnesjælen, aldeles naturlig skjønt i længere Tid for Barnet selv ubevidst" (Faber 1842, 32). Selv om det eksplicit afvises af både Martensen og Faber, synes dog begge at tillægge dåben en magisk kraft - for nu at bruge Schleiermachers udtryk (Schleiermacher 1831, bd. 2, 32).

Diskussionen om dåben blev retningsgivende for hele Eiríkssons senere, relativt omfattende forfatterskab, der udviklede sig i stadig mere radikal retning, kirkeligt set. Centrale dogmer som dogmet om Kristi guddommelige natur (to-naturlæren) og treenighedsdogmet endte med at blive forkastet, ligesom han afviste Johannesevangeliet som uægte. Allerede i sit første værk hævdede han i lighed med baptisterne, at barnedåben ikke kunne begrundes ud fra Det Nye Testamente, og afviste, at dåben var et sakramente. Af de danske teologer var især H.L. Martensen genstand for hans kritik. ${ }^{8}$ Også imod Faber rettede han det svære skyts. Men svar fik han aldrig. Selv skrev han, at hans modstandere synes at være bange for hans skrifter og derfor søgte at tie dem ihjel. ${ }^{9}$ Det må også siges at

8 Om Eiríkssons kritik af Martensen (Schreiber 2009a og 2012), Schreibers artikler indeholder talrige litteraturhenvisninger.

9 I flere af sine arbejder kommer han ind på linjerne i sit forfatterskab og den manglende respons, men den bedste oversigt over sine intentioner med de enkelte værker gav han i en serie af artikler med overskriften "Min Forfattervirksomhed", som han fik offentliggjort i Vilhelm Møllers Flyvende Blade for Literatur, Kunst og Samfundsspørgsmaal (Eiríksson 1875). 
være lykkedes. I dag huskes kun det varme forsvar i Breve til Clara Raphael (Immanuel 1851), som han udgav under pseudonymet Theodor Immanuel, for den unge kvindesagsforkæmper Mathilde Fibiger (1830-72), som under pseudonymet Clara Raphael i 1851 havde udgivet Tolv Breve (Raphael 1851), hvori hun argumenterede for, at kvinder havde samme ret som mænd til at vælge deres livsbane. ${ }^{10}$ Langt de fleste af Eiríkssons mange udgivelser er glemt og næppe til at opstøve. ${ }^{11}$

\section{Grundtvigs opfattelse af dåben}

Efter i en årrække at have beskæftiget sig med verdens- og kulturhistorie og med oversættelser af historieværket Heimskringla, som er tilskrevet islænderen Snorri Sturluson (ca. 1178-1241), af historieværket Gesta Danorum (Danskernes bedrifter) forfattet af Saxo Grammaticus (født omkring 1160) og af det oldengelske helteepos Beowulf, som sandsynligvis stammer fra det ottende århundrede, blev Grundtvig i 1821 præst i Præstø, en lille, stille købstad på Sjælland. Da han drømte om at opvække danskerne til sand kristendom, ja, næsten om at genkristne Norden ved, som han havde forsøgt i sin ungdom, at "vække Nordens Folk af den dybe Sjæle-Søvn paa Afgrundens Bredd” (US 4, 240), genopvække oldtidens kæmpeånd og kalde den til kamp for kristendommen, følte han sin virkekreds for snæver i den lille provinsby og ønskede sig til hovedstaden. Skønt han ikke var velset i kirkelige kredse, blev han i 1822 kaldet til kapellan ved Vor Frelsers Kirke på Frederikshavn. Men mismodet kom over ham, idet han følte, at selv om han var en søgt prædikant, lykkedes det heller ikke i København at opnå tilstrækkelig lydhørhed. I slutningen af 1823 oplevede han dog, at livsmodet vendte tilbage, "at Natten var forgangen, og Dagen kommet nar" (US 4, 244), og beskrev hen over sommeren 1824 i det store digt Nyaars-Morgen på 312 11-linjede strofer i allegorisk form sin udvikling og karakteriserede den periode, hvor han virkede som oversætter, som

${ }^{10}$ Om Clara Raphael-fejden, som er omtalt mange steder, se især Bajer (1879) og Nun (2013, 85-111), hvor der gives relativt udtømmende henvisninger til litteratur om Mathilde Fibiger og fejden.

11 En bibliografi over Magnús Eiríkssons talrige skrifter og artikler findes i Schreiber (2009b, sp. 517-33). 
et natteophold i de dødes rige. Men nu anede han, at det håb, han havde næret, ville gå i opfyldelse, "og vel maatte da min Morgen-Hilsen blive, i det Mindste for mig selv, en Morgen-Psalme” (US 4, 245). Men hermed var hans trængslers tid ikke forbi.

Tilblivelsen af Grundtvigs optimisme havde en lang historie bag sig. Efter i sin ungdom at have beskæftiget sig intenst og begejstret med Nordens mytologi ramtes han i december 1810 af en depression, der førte ham til randen af sindssyge, og som fik ham til at opleve, at han kæmpede for sin sjæls frelse (Rønning 1907-1914, 2,1, 195-98). Ikke mindst fordybelse i Bibelen hjalp ham ud af krisen og førte ham til en stærk luthersk overbevisning om Bibelens betydning som kirkens norm og autoritet.

Netop denne tro eller det synspunkt, som han dengang havde opnået og også havde forfægtet gennem 1810'erne, havde Grundtvig ikke forladt, da han blev præst i København fra 1822. Problemet var de mange præster, der var uddannet i det sene 18. århundredes rationalistiske teologi, ifølge hvilken lægmænd om søndagen i kirken og ved konfirmationsundervisningen først og fremmest skulle indprentes den moralske belæring, der kunne udledes af evangelierne. Herigennem fordrejedes det kristne budskab for lægfolket, der med det begyndende frembrud af vækkelserne også selv i stigende grad læste i Biblen. Når de rationalistiske præster eksempelvis forsøgte at bortforklare Kristi mirakler som naturlige hændelser eller anvendte bibelkritikkens indsigelser mod ægtheden af samtlige af de breve, som var overleveret under Paulus' navn, såvel som mod ægtheden af Johannesevangeliet, skabtes der tvivl og usikkerhed hos den sandhedssøgende lægmand, mente Grundtvig. Han fandt det med andre ord ubærligt, at en række af statskirkens præster og de teologiske professorer ved Københavns Universitet således formidlede deres falske lærdomme fra prædikestolene og i auditorierne.

Det var bl.a. som et led i disse bekymringer, at Grundtvig gjorde den opdagelse, som Kierkegaard siden hen formentlig som den første med slet skjult ironi betegnede som mageløs (se f.eks. SKS 7, 43). Opdagelsen blev som bekendt afgørende for den resterende del af hans liv og for de mennesker, der sluttede sig til ham.

Hvor der i katolsk teologi opereres med syv sakramenter eller nådesmidler, regner den lutherske teologi kun med to, dåben og nadveren. Hvor Kristi indstiftelse af nadveren fremgår af de tre synoptiske evangelier, har dåben - forstået som barnedåben - været mere omdiskuteret. For Grundt- 
vig var der ingen tvivl. Begge nådesmidler blev indstiftet af Kristus, og i de ord, der indgår i både dåbs- og nadverritualet, og som - mente Grundtvig - $\mathrm{i}$ en ubrudt tradition er blevet brugt siden, hører vi Kristi egne ord ved indstiftelsen. Det samme gælder Den Apostolske Trosbekendelse, som er en del af dåbsritualet, dvs. at i og med denne trosbekendelse har kirken og menigheden Kristi bestemmelse af den sande kristendom. ${ }^{12}$ Hvis dette var tilfældet, var der ingen grund til at bekymre sig om den videnskabelige bibelkritik, hvorfra vantroen drog sin næring. Første gang Grundtvig udtalte denne opfattelse, var i sin prædiken søndag d. 31. juli 1825. ${ }^{13}$ Mange år senere skrev den over 80 -årige Grundtvig om sin opdagelse,

at hvis Skriften var den Christne Menigheds Troes-Regel, da vilde Vantroen nu, da næsten alle de Skriftkloge hyldede den, have en langt gyldigere og stærkere Vidnesbyrd end Troen, som kun nogle enkelte Skriftkloge bevidnede, og min Slutning blev da, at saavist som Jesus Christus var Gud-Faders eenbaarne Søn, saavist maatte der ogsaa i Kirken findes et langt gyldigere og stærkere Vidnesbyrd om den ægte, oprindelige, Christne Tro, end Bogstav-Skriften paa nogen Maade

12 Grundtvig synes i begyndelsen kun at ville henføre dåbsritualets oprindelse til apostolisk tid, dvs. tiden efter Kristi himmelfart. Således i sit teologiske hovedværk, artiklerne i Theologisk Maanedsskrift om den sande kristendom og om kristendommens sandhed fra 1826-27, optrykt i US 4, 443-723, hvor han skriver, at den tro, der kommer til udtryk i den apostolske trosbekendelse "fra Apostlernes Dage uafbrudt forplantedes med Daaben fra Slægt til Slægt og fra Folk til Andet" (US 4, 535). Senere i artikelserien synes han imidlertid at implicere, at indholdet af hele dåbsritualet, dvs. også den apostolske trosbekendelse, stammer fra Kristi indstiftelse af dåben. F.eks. skriver han, at hvis vi ikke forretter "Daaben i alle Maader efter Christi Indstiftelse, [...] da ere vi falske Christne" (US 4, 616 f.), og siger til en forestillet modstander: "Beviis derfor, om du kan, enten at DjævleForsagelsen, Troes-Bekjendelsen og Synds-Forladelsen ei oprindelig hører til den christelige Daab" [...] (US 4, 618). Både i indledningen til Christenhedens Syvstjerne fra $1860 \mathrm{og}$ i et efterskrift fra 1865 til anden udgave af afhandlingerne siger han eksplicit, at indholdet af dåbsritualet, den apostolske trosbekendelse indbefattet, kan henføres til Kristi "Aand og evige Munds-Ord" (se Grundtvig 1860, XI, og US 4, 726). Hvorledes forskydningen i Grundtvigs opfattelse kom til orde i den prædikensamling, som han udgav i årene 1827-31 (Søndagsbogen, bd. 1-3), se Begtrup 1936, bd. 1, 132-37.

13 Den bevarede del af denne prædiken er efter Grundtvigs manuskript trykt i Begtrup 1901, 190-197, og US 4, 387-94. 
kunde være for Kvinder og Børn og alle de Ulærde. Da jeg nu i denne Retning uafladeligt grublede, læste og skrev under Bøn og Paakaldelse, see! da slog det mig i et velsignet Øieblik, at det magelose Vidnesbyrd, jeg saa møisommelig ledte om i hele Aandens Verden, det giennemlød som en Himmel-Røst hele Tiden og Christenheden i den apostoliske Troes-Bekiendelse ved Daaben (Grundtvig 1871, 385).

Allerede kort efter at Grundtvig havde gjort sin mageløse opdagelse, indledtes med det lille kampskrift Kirkens Gienmale, som udkom 5. september 1825, den bekendte strid med H.N. Clausen. Clausen anlagde en injurieproces, som Grundtvig tabte. Det var ikke mindst Grundtvigs ord om, at Clausen havde stillet "sig i Spidsen for den Christelige Kirkes Fiender og Guds Ords Foragtere i Landet” (US 4, 397), der naturligt nok havde bragt den teologiske professor i harnisk. Mange år senere skrev Clausen i sine erindringer om Kirkens Gienmale, at det lille skrift var udslag af, hvad Melanchthon havde kaldt "rabies theologorum", teologisk rasen (Clausen 1877, 109). Resultatet blev, at Grundtvig i oktober 1826, da dommen faldt, blev dømt for injurier. Han var også blevet pålagt censur, som først blev ophævet i 1837. Allerede i maj samme år, som injurieprocessen foregik, havde han nedlagt sit embede.

I Kirkens Gienmale beskyldte Grundtvig H.N. Clausen for, at han i sin bog Catholicismens og Protestantismens Kirkeforfatning, Lare og Ritus ${ }^{14}$ lod "den falske, kiødelige Fornuft", som er den kristne kirkes arvefjende (US 4, 405), være den instans, som afgør, hvad der er sand kristendom: at det skrevne ord, dvs. Det Nye Testamente fortolket i fornuftens lys, gøres til målestokken. Hermed tillægges tiden mellem kristendommens første tid og nutiden ingen betydning. Men hverken fornuften eller det døde bogstav er Kirkens og kristendommens fundament: "[D]en eneste sande, almindelig (catholsk) christelige Kirke, som ene hviler paa et historisk Fundament, maa nødvendig staae og falde med Historiens Vidnesbyrd" (US 4 , 403). Den ubrudte, levende tradition siden Kristus, gennem hvilken dåbsritualet og Den Apostolske Trosbekendelse er mundtligt formidlet til nutiden, er det grundlag, som den sande kristendom, der manifesterer sig i menighedslivet, hviler på. Skønt romerkirken, som Grundtvig

14 Som blot var udkommet 3. september 1825, men som Grundtvig havde været bekendt med et par uger før udgivelsesdagen. 
kritiserede skarpt, har fordrejet og forfalsket den sande lære, har den dog fra generation til generation siden apostlene og oldkirken viderebragt den uforfalskede kristendom.

Grundtvigs opfattelse kunne kritiseres og blev det. Det blev indvendt, at historisk set kunne den apostolske trosbekendelse ikke føres tilbage til Kristus, og at Grundtvig ved at bygge på den historisk foreliggende tradition afveg fra det protestantiske skriftprincip og dermed havde nærmet sig en anskuelse, der var i slægt med katolicismens opfattelse af, at de kristne dogmer ikke kun bygger på Bibelens ord, men også på den kirkelige tradition. Beskyldningen for at have en tendens til katolicisme fulgte Grundtvig hele livet, selv om han allerede i december 1825 havde afvist beskyldningen som "barnagtig Snak", ${ }^{15}$ men at Grundtvig ikke helt kan siges fri for en sådan tendens, fremgår af, at han og hans tilhængere i lighed med katolicismen betonede kirkens autoritet. Men katolicismens appel til kirkens tradition er en anden end Grundtvigs, idet Grundtvigs henvisning til kirkehistorien kun angår, hvad der ud fra denne kan fastslås er den oprindelige apostolske kristendom og derfra er overleveret gennem kirkens historie, hvorimod katolicismen også lader sand kristendom omfatte vedtagelser på kirkemøder og pavens udtalelser "ex cathedra".

Gudstjenestens form havde siden Danmarks og Norges Kirkeritual af 1685 ligget fast. Som tiden var gået, var imidlertid en vis tolerance blevet tålt af den kirkelige øvrighed, og fra slutningen af 1820'erne og i mere end et tiår frem blev der i aviser, tidsskrifter og småskrifter ført en heftig debat om den manglende ensartethed i den danske statskirke. H.N. Clausen mere end antydede i 1825, at ingen gejstlig i Danmark holdt sig til de gældende retningslinjer, og foreslog derfor nogle reviderede formuleringer, som kunne skabe ensartethed i sakramenternes forvaltning (Clausen 1825, 833-39). Clausens forslag vandt dog ikke tilslutning. Resultatet af

15 Afvisningen forekommer i Grundtvigs anmeldelse i tredje bind fra 1825 af Theologisk Maanedsskrift af kirkehistorikeren August Neanders bog Antignosticus, Geist des Tertullianus und Einleitung in dessen Schriften (Grundtvig 1825, 248278). Grundtvig skriver her, at når man, som han hævder, "at det ene og alene er den christelige Kirke-Historie, som kan lære os, hvad de Christne har troet, altsaa hvad Christendom er", så straffes man med at blive kaldt "Obskuranter og Catholiker" (249), og at der skal andet og mere til at tilbagevise en sådan beskyldning "end fornemme Skulder-Træk, og den barnagtige Snak, at jeg er blevet catholsk (...)" (274). 
diskussionen blev, at Det danske Kancelli i 1837 overlod til biskop Mynster at udarbejde et samlet forslag til en ny ritual- og alterbog. Mynster gik straks i gang med arbejdet, og i 1839 blev hans forslag udgivet (Mynster 1839). ${ }^{16}$ Han foreslog her adskillige ændringer i de tidligere fastlagte ritualer. F.eks. foreslog han, at ritualet i forbindelse med voksendåb skulle afvige fra det, der skulle anvendes ved barnedåb.

Nok var Mynster tilhænger af en vis forkyndelsesfrihed både i forbindelse med prædikener og ved begravelser og vielser. Men han var modstander af, at præsterne frit kunne ændre de kirkelige ritualer i forbindelse med f.eks. dåb og nadver. Derfor var der med Mynsters ordlyd tale om et forslag til en forordnet ritual- og alterbog for den danske statskirke. ${ }^{17}$

Grundtvig vendte sig i et kampskrift med titlen Frisprog fra samme år på overfladen venligt, men i virkeligheden meget skarpt imod Mynsters forslag, ${ }^{18}$ idet han på den ene side mente, at der ingen grund var til at ændre ritualerne, og på den anden side ville holde fast ved præsternes hævdvundne ret til at modificere dem, hvis deres samvittighed tilsagde det. "Samvittigheds-Friheden" - dvs. friheden til at følge sin samvittighed i trosanliggender - havde Grundtvig skrevet i Den Danske Stats-Kirke upartisk betragtet i 1834, "er al Religjons øverste Grund-Sætning og enhver ustraffelig Borgers utabelige Ret” (US 8, 57). Der er næppe nogen tvivl om, at Mynsters brug af ordet "forordnet" har virket stærkt provokerende på ham, og modsat biskoppen var han en varm fortaler for muligheden af at løse sognebånd, dvs. at borgerne frit kunne vælge, hvilken præst de ville gå til i kirkelige anliggender. Grundtvig havde endog allerede i en afhandling i tre dele fra 1827, hvoraf censuren havde forbudt den tredje at udkomme, gjort sig til talsmand for retten til fri religionsudøvelse - dog med visse ikke specificerede begrænsninger - og hævdet, at både fornuften og historien tilsiger, at "Frihed er Aandens Element, som Tvang er

\footnotetext{
16 Udkastet består af tre dele: I. Forslag til Forordnet Alterbog for Danmark, II. Forslag til Kirke-Ritual for Danmark og III. Bemærkninger ved Forslagene til en ny Alterbog og et nyt Kirke-Ritual.

17 Hele ritualsagen er indgående skildret i Rasmussen 1999, 145-72.

18 N.F.S. Grundtvig (1839), Frisprog mod H[ans] H[øjærværdighed] Hr. Biskop Mynsters Forslag til en ny Forordnet Alterbog, Kjøbenhavn, Wahl, optrykt i US 8, 209-98.
} 
Kroppens", 19 idet "Kroppens Frihed" altid gør skade, men åndens frihed altid gør gavn (US 5, 69). Han ønskede derfor, at det tætte bånd imellem stat og kirke, som karakteriserede den danske enevælde, skulle løsnes, og at det skulle være muligt at udmelde sig af statskirken, hvilket Mynster af al magt kæmpede imod.

Grundtvigs hovedanliggende var at forhindre en ændring af dåbsritualet, hvilket lykkedes, da den nyligt kronede Christian 8. (1839-48) og især hans dronning var langt mere positivt sindet over for Grundtvig, end forgængeren Frederik 6. havde været. Mynsters forslag blev derfor aldrig ført ud i livet. Grundtvig havde også i sit indlæg mod Mynster fortrøstningsfuldt givet udtryk for, at han forventede, at "Majestæten, under alle Omstændigheder, vilde tillade os ældre Præster at døbe fremdeles som hidtil" (US 8, 227).

At det var ordet "forordnet", der havde stødt Grundtvig, fremgår med al ønskelig tydelighed af hans indsigelser mod Mynsters forslag. Han siger her klart, at hvis Mynster havde foreslået, at det var muligt at udtræde af statskirken og danne en frikirke, ville han ikke have udgivet sine indsigelser. Grundtvig argumenterede i sit modskrift ikke for sin opfattelse af dåbsritualet og Den Apostolske Trosbekendelses oprindelse, skønt netop denne trosbekendelse spiller en væsentlig rolle for mange teologers opfattelse af dåben som en pagt med det guddommelige, idet den døbte i trosbekendelsen f.eks. forpligter sig til at "forsage Djævelen og alle hans gerninger”. Grundtvig ønskede netop ikke i forbindelse med sin kritik at indlade sig i teologiske diskussioner, men nøjedes med at sige, at Mynsters forslag var uansvarligt, fordi det, hvis det blev lov,

vilde berøve alle de Børn, der herefter fødes, Stats-Kirkens Daab i sin gamle Skikkelse, den Eneste der kan være den Oprindelige efter Christi Indstiftelse, og paalægge os Præster, hvad der strider mod vort Ordinations-Løfte, at forrette Daaben i en Skikkelse, som, da den er splinterny, umuelig kan være efter Christi Indstiftelse (US 8, 229).

\footnotetext{
19 N.F.S. Grundtvig, “Om Religions-Frihed” 1-3, hvor de to første udkom i Theologisk Maanedsskrift, januar og februar 1827, US 5, 46-153. Det citerede er fra den anden artikel, US 5, 86. Grundtvigs forbehold over for fuldstændig religionsfrihed fremgår f.eks., hvor han skriver, at de protestantiske sømagter indrømmer beboerne i kolonierne "en saa udstrakt Religions-Frihed, at lidt mindre var meer end nok!” (US 5, 57).
} 
Mynster svarede sine kritikere og især Grundtvig i et lille skrift, der udkom i 1840. Her bemærkede han blandt andet, at Grundtvigs fremhævelse af den mundtlige overlevering som højeste instans strider mod den almene opfattelse af, at mundtlige overleveringer, som har strakt sig over århundreder, er upålidelige. Grundtvig havde også i sit Frisprog skrevet - citerer Mynster - at "den Danske Kirke kun er et Brudstykke af den Romerske Kirke-Stat, hvorfra vi har faaet Troen og Sacramenterne" (US 8, 248, og Mynster 1840, 32); men Mynster undlader at citere hele den sætning, hvori det citerede indgår, og som begynder: "Mine Læsere maae vide, jeg er langtfra at være partisk for Rom i nogen af sine Tyran-Skikkelser”. I forlængelse af sit citat peger Mynster også på, at Grundtvig i anden forbindelse uden videre beråber sig på, hvad der er skik i den katolske kirke, og kan herefter fortsætte: "Saaledes ere vi da lykkelig ankommet for Pavens fødder” (Mynster 1840, 33). I sin kritik af Mynster havde Grundtvig ikke altid været helt retfærdigt. F.eks. havde han beskyldt biskoppen for at stræbe efter, at hans personlige opfattelse skulle være lov (US 8, 270). Men som det fremgår, holdt heller ikke Mynster sig tilbage.

\section{Grundtvig og forfølgelsen af baptisterne}

Allerede før lovfæstelsen af tvangsdåben havde fundet sted, vendte Grundtvig sig i et hastigt affattet flyveskrift imod den forfølgelse, som baptisterne var genstand for (Grundtvig 1842). Det var ikke baptisternes opfattelse af voksendåb versus barnedåb, som han ville forsvare - her var uenigheden mellem ham og baptisterne afgrundsdyb - men fordi han som talsmand for religionsfrihed, dvs. for, at hver enkelt samfundsborger i et kristent land må dyrke den kristne gud, som hans samvittighed tilsiger ham, ikke stiltiende kunne være vidne til myndighedernes fremfærd imod baptisterne, som han i lighed med andre fejlagtigt betegnede som gendøbere. I sit forsvar for baptister gjorde Eiríksson derfor indledningsvist rede for, at baptisterne ikke måtte slås i hartkorn med de døbere eller anabaptister, der fordømmes i den augsburgske konfession (Eiríksson 1844, 3-31).

I flyveskriftet stillede og besvarede Grundtvig tre spørgsmål. For det første: Hvad er religionsforfølgelse? For det andet: Er religionsforfølgelse i overensstemmelse med Kongeloven, Den Augsburgske Bekendelse og den kristne tro? Og for det tredje: Viser erfaringen, at religionsforfølgelse 
nogen sinde har bidraget til fred og fordragelighed i en stat? Hvor de to første spørgsmål diskuteres på baggrund af forholdene i Danmark, henter Grundtvig materiale fra en lang række europæiske landes historie i besvarelsen af det tredje.

Det første spørgsmål besvarer Grundtvig ved at fastslå, at der foreligger religionsforfølgelse, når staten straffer personer, der udøver og udbreder en gudsdyrkelse, der afviger fra statskirkens. Hertil kunne indvendes, skriver han, at der i formel henseende ikke straffes for at gøre dette, men for at overtræde gældende love. Men ud fra en sådan betragtning er forfølgelsen blot en lovmæssig forfølgelse, hvilket ikke ændrer ved det forhold, at man gør de forfulgte til martyrer for en samvittighedssag. Da Luther (14831546) i modsætning til katolicismen havde hævdet, at mennesket i religiøse anliggender bør følge sin samvittighed, strider religiøs forfølgelse mod den lutherske kristendom og kan hverken, mente Grundtvig, begrundes ud fra Det Nye Testamente eller ud fra den sande kristendom.

Med hensyn til det andet spørgsmål er Grundtvigs svar, at Kongeloven i religiøse anliggender henviser til Den Augsburgske Bekendelse og både skal beskytte denne og kristendommen. Da bekendelsen forudsættes ikke at være i strid med den sande kristendom, kan den ikke retfærdiggøre religiøs forfølgelse. Tværtimod, "thi at den Augsburgske Confession udtrykkelig protesterer mod al Religions-Forfølgelse, det er unægteligt" (US $8,463)$. Her er Grundtvig måske på lidt tynd is. Det er kun, fordi bekendelsen antages at være i overensstemmelse med, hvad Grundtvig mener er sand luthersk kristendom, at den kan siges at afvise religiøse forfølgelser.

Ikke alene er religionsforfølgelse derfor både ukristelig og anti-luthersk, men er også i Danmark

aldeles unaturlig, og under vor Stats-Kirkes indvortes opløste, forvirrede Tilstand, saa aabenbar ubillig og urimelig, at Religions-Forfølgelse ingensteds og til ingen Tid (skiønt det vil sige meget) har gjort saa stor en Ulykke, som den vil giøre her, hvor den kun ved et Mirakel hidtil er hindret fra at giøre Stats-Kirkens bedste Venner til dens Fiender, kaste Regieringens troeste Tilhængere i Oppositionens Arme, og ødelægge det fredeligste og kiærligste Folkeliv, der har blomstret på Jorden! (US 8, 472) 
Det tredje spørgsmål mener Grundtvig at kunne besvare med henvisning til, at historien viser, at religionsforfølgelse ikke formindsker, men snarere fremmer splid og uenighed i en stat. Gentagne gange understreger han, at det er lavsinteresser, der står bag statsgejstlighedens kamp imod en fra statskirken afvigende gudsdyrkelse, og hvis man "vil vente paa Friheden, til den anbefales af en Stats-Geistlighed i det Hele, maa man sikkert vente til Tusindaars-Riget kommer" (US 8, 473).

\section{Eiríkssons kritik af Grundtvigs forsvar for baptisterne}

Det 18. og 19. århundredes historisk-kritiske bibelfortolkning og det 18 . århundredes teologiske rationalisme, som især havde søgt at formidle evangeliernes moralske indhold, fremkaldte i første halvdel af det 19. århundredes Danmark to store og en lille reformator. De store var Grundtvig og Søren Kierkegaard (1813-55), selv om sidstnævnte i 1855 afviste at være en reformator, ${ }^{20}$ den lille Eiríksson. Eiríksson besad dog hverken Grundtvigs poetiske og visionære kraft eller Kierkegaards dialektiske skarphed og litterære færdigheder, og hvor de to første i anden halvdel af det 19. århundrede og første halvdel af det 20. fik stor indflydelse på det kirkelige og religiøse liv i Danmark, forblev Eiríkssons reformatoriske bestræbelser totalt virkningsløse. ${ }^{21}$ Enkelte blandt det 20. århundredes religiøst interesserede husker ham blot som "Den første Forkynder af Unitarisme i Danmark" (Kierkegaard 1958).

Grundtvigs svar på bibelkritikkens udfordring er allerede blevet fremstillet. Det går i al korthed ud på, at det ikke er "Skriften, der kan eller skal forsvare Kirken, men Kirken, der skal forsvare Skriften” (US 4, 553). Det troens ord, som udsiges i kirken, det levende ord, skal besjæle enhver læsning af Bibelen. For Kierkegaard var svaret troen på inkarnationen og

\footnotetext{
20 "[J]eg er ikke, hvad Tiden maaskee kræver, en Reformator" (SKS 14, 169).

21 I 1830-31 argumenterede Grundtvig i artikelserien "Skal den Lutherske Reformation virkelig fortsættes?" for en fortsættelse af den lutherske reformation "paa en christelig Maade" (se f.eks. US 5, 319). Kierkegaards ønske om en kirkelig reformation fremgår ikke mindst af hans kritik i tidsskriftet Øieblikket af den formidlingsteologi, som Mynster og Martensen stod for, og Eiríksson skriver direkte, at "den Lutherske (navnlig danske) Statskirke meget haardt trænger til en Reformation” (Eiríksson 1844, XLIV).
} 
Kristi offerdød. Denne tro alene forløste det eksisterende og syndige menneske. Desuden var det den enfoldige, barnlige fromhed, som var målet for individets religiøse udvikling, og denne fromhed ville man ikke kunne opnå gennem teologiske spekulationer, mente han. Hvor Grundtvig fandt bibellæsningens forudsætning uden for mennesket, nemlig i den kirkelige tradition, dvs. i noget objektivt, fandt Kierkegaard og Eiríksson den i noget subjektivt, nemlig i den individuelt opnåede personlige fromhed, den første i troen på inkarnationen og Kristi offerdød, den anden i, hvad han mente var kristendommens ånd, nemlig kærlighed til Gud og kærlighed til næsten. Gentagne gange understregede Eiríksson

Nødvendigheden af et vist Sindelag, forat der kan være grundet Haab om, at man kan forstaae og forklare Skriften overensstemmende med Christendommens Aand. [...] Og hvilket er da dette Sindelag? vil man spørge. Det er en vis Fromhed, en Sindets Henbøien eller Retning til Gud i Almindelighed, eller andre Ord: Religiøsitet (Eiríksson 1844, XXII), ${ }^{22}$

men han fandt samtidig, at kirkens læresætninger og ritualer - og hermed også kirkens symboler, dvs. dens bekendelsesskrifter - skulle reformuleres ud fra de resultater, som den historiske bibelkritik var nået frem til, idet kun det, der var i overensstemmelse med en af kærlighed beåndet fornuft, "den oplyste christelige Forstand" (Eiríksson 1844, VIII), ${ }^{23}$ kunne accepteres. Og hvor Grundtvig og Kierkegaard på højst forskellige grundlag begge var forkyndere, fremtrådte Eiríksson først og fremmest som en lidt primitiv og påståelig videnskabelig teolog, hvilket utvivlsomt var en af årsagerne til hans manglende gennemslagskraft.

Allerede tidligt i Om Baptister og Barnedaab møder vi kritikken af Grundtvig for katolicisme, men på et lidt dubiøst grundlag, nemlig ud fra en erklæring om baptisternes anskuelser, som baptisten Peter Christian Mønster (1797-1870) i 1839 blev afkrævet af myndighederne.

Mønster var uddannet gravør og havde boet i Slagelse, hvor han havde holdt gudelige forsamlinger, dvs. forsamlinger af religiøst vakte lægmænd.

22 På dette punkt var Eiríksson enig med stort set alle kristne teologer.

23 Om Eiríkssons noget hjemmestrikkede bestemmelser af fornuft og forstand og af forholdet mellem dem, se Koch 2017b, 17-54. 
Da denne aktivitet blev forbudt af bystyret, flyttede han til Skælskør og senere til København, hvor han sluttede sig til kredsen omkring Grundtvig; men da han kom i tvivl om, at barnedåben var den af Kristus indstiftede dåb, gik han over til baptisterne. Han blev derfor genstand for myndighedernes forfølgelse, blev idømt bøder og tilbragte mellem 1839 og 1845 fire år i fængsel på grund af sine religiøse anskuelser.

I sin erklæring skriver Mønster bl.a., at Grundtvig under en samtale med ham havde sagt, "at Lægfolk skulde afholde sig fra at læse Bibelen og granske i den, da de ikke havde den Helligaand, som Præsterne fik ved Haandspaalæggelsen, og dem var det, som ene forstod den" (Eiríksson 1844,21$)$. Ikke mindst denne holdning hos Grundtvig viser, mener Eiríksson, det "catholske Element" i hans kirkelige opfattelse og en "gediegen Catholicisme" (Eiríksson 1844, 22, fodnoten).

At Grundtvig i 1830'erne ordret skulle have sagt, som Mønster refererer, er næppe troligt, idet han på intet tidspunkt, ud fra hvad vi ved, har villet afskære lægmænd fra bibellæsning. Imidlertid er det tænkeligt, at han har sagt noget om håndspålæggelsen ved præsteordinationer, som Mønster har fejltolket. Grundtvig havde i nogle artikler fra 1826-27 om kristendommens sandhed skrevet, at

$\mathrm{Nu}$ vidner Kirke-Historien, at Aanden og Livet skjænkes i Christi Menighed, almindelig i en vis Orden, og kun ved en Undtagelse, tillige som overordentlig Naade-Gave, saa at ordentligviis annamme alle Troende Aanden og Livet ved Daaben og Nadveren, og alle troende Skrift-Kloge aandelig Dygtighed til Lære-Embedet ved Haands-Paalæggelsen; medens Herren og Aanden have forbeholdt sig at skjænke og uddele overordentlige Naade-Gaver, efter Troens Maal og Menighedens Tarv, til hvem de vil (US 4, 702).

Indholdet af denne udtalelse er klart i modstrid med den opfattelse, som Mønster og Eiríksson tillægger Grundtvig. For øvrigt synes Grundtvig ved genudgivelsen i 1865 af artiklerne at kaste tvivl over den historiske baggrund for håndspålæggelsen ved præsteordinationen.

Ud fra sit daværende stadium som skriftteolog måtte Eiríksson også forarges over Grundtvigs karakteristik af Bibelen som "døde Bogstaver" (f.eks. US 4, 549 og 554 f., Eiríksson 1844, 26, note ${ }^{* *}$ ). Men her er der tale om en misforståelse, idet Grundtvig mente, at Skriftens "døde Bog- 
stav" skal beåndes ved at blive læst i kristelig ånd. Det var også Eiríkssons egen opfattelse.

I forbindelse med Grundtvig har Eiríksson haft to anliggender, nemlig dels en kritik af Grundtvigs lille pjece Om Religions-Forfolgelse, dels har han villet understrege, at Grundtvig - som Faber og Martensen - i sin fremhævelse af barnedåben var i strid med Det Nye Testamente.

Et særligt afsnit af Om Baptister og Barnedaab er viet til kritikken af Grundtvigs forsvarspjece (Eiríksson 1844, 99-138). Eiríksson kritiserer her Grundtvig for, at hans forsvar ikke er udtryk for en religiøs tolerance udsprunget af, hvad Eiríksson kalder "Christendommens KjærlighedsPrincip” (127), og er i strid med Grundtvigs religiøse personlighed. Som Grundtvig selv skrev, havde han ikke den mindste sympati for baptisterne. ${ }^{24}$ Derfor er, mente Eiríksson, forsvaret ikke oprigtigt og ægte, og Grundtvigs ønske om religiøs tolerance er ikke udsprunget af et kristent sindelag. Grundtvig var, hævdede Eiríksson, i religiøs henseende slet ikke tolerant, og han henviste til, at han i sit Frisprog kort havde afvist dem, der havde en anden opfattelse af nadveren end den lutherske, dvs. Calvin og Zwingli og deres tilhængere, som "Vrævlerne" (US 8, 242, Eiríksson 1844,99 , note ${ }^{*}$. Da Grundtvig havde en fundamentalt anderledes dåbsopfattelse end baptisterne, var et forsvar for dem, mente Eiríksson, i strid med hans dybeste overbevisning, og det var derfor inkonsekvent af ham at føre et sådant forsvar for dem. Et ægte forsvar for dem måtte være gennemtrængt af kristen kærlighed og ikke af verdslig klogskab og historiske erfaringer.

De grunde, som Grundtvig fremlagde imod religionsforfølgelse, afviste Eiríksson således som udvendige, verdslige og formelle.

Når Grundtvig i afvisning af religionsforfølgelse henviser til Kongeloven, hvor der intet eksplicit står om denne sag, må det være, fordi statsmagten ifølge loven er forpligtet til at håndhæve Den Augsburgske Bekendelse; men i denne er heller ikke eksplicit dikteret religiøs tolerance. Snarere tværtimod, idet der f.eks. bruges hårde ord imod døberne, som fordømmes. I Den Augsburgske Bekendelse findes der således en spire til religiøs intolerance, mente Eiríksson. Rigtigt er det, at Luther og hans tilhængere appellerede til kejserens og pavestolens tolerance, men nedadtil opviste de ikke nogen tolerant holdning. Og at henvise til Kongeloven er

${ }^{24}$ I Om Religions-Forfolgelse, US 8, 471. 
et rent formelt argument. En lov kan fortolkes på mange måder, og at henvise til lovbestemmelser nytter derfor intet, da - skriver Eiríksson - den verdslige visdom adsplitter, hvorimod den himmelske kærlighed forener (Eiríksson 1844, 116). Kun hvis der ved læsningen af Skriften og Den Augsburgske Bekendelse appelleres til den kristne kærlighed, kan det siges, at religionsforfølgelse strider mod den kristne tro, skønt der ingen af stederne står noget derom.

Også Grundtvigs henvisning til erfaringer er forfejlet, idet der stadig væk er tale om en ydre grund til at undgå religionsforfølgelse, en klogskabsregel, der siger, at religionsforfølgelse er farlig for staten, idet den skaber indre splid og ufred og er kilde til sekteriske bevægelser. Som klogskabsregel er den et produkt af den verdslige fornuft og ikke udsprunget af kristen kærlighed. Hertil kommer, skriver Eiríksson,

at denne Klogskabsregel viser sig, som de fleste Klogskabsregler, meget kortsynet og eensidig; thi den Fare, som der sigtes til, naar Talen er om de religiøse Secter, bestaar i den Bevagelse, som det er rimeligt at disse ville foraarsage; men hvem tør vel paastaae: at Bevægelse ikke ligesaa ofte, maaske meget oftere, ere gavnlige, end skadelige? Dette maa isar antages at gjælde paa det religiøse Gebet; thi Kirkens Historie viser, at slige Bevægelser som oftest havde gavnlige Følger (Eiríksson 1844,110 f.).

I sin iver for at gendrive Grundtvig har Eiríksson slet ikke påvist, at Grundtvigs klogskabsregel er kortsynet og ensidig, men kun hævdet, at religiøs forskellighed kan være en fordel for et samfund, hvilket Grundtvig ville have været enig med ham i. Eiríkssons kritik af Grundtvig rummer dog også implicit og formentlig utilsigtet en delvis retfærdiggørelse af religionsforfølgelse. Hvis sektdannelse er en af virkningerne af religionsforfølgelse, og sekter kan indvirke gavnligt på en nations religiøse liv, kan forfølgelser af religiøse grunde ikke absolut fordømmes. Det er langtfra enestående i Eiríkssons forfatterskab, at hans polemiske temperament løber af med ham.

Grundtvigs forsvarsskrift vil i det lange løb, mente Eiríksson, skade baptisterne. I pjecen kritiserer han den danske gejstlighed og fremhæver sig selv, hvilket umiddelbart vil fremkalde en uvilje mod baptisterne hos ledende kirkefolk og statsadministrationens embedsmænd. Eiríksson har 
tilsyneladende ikke overvejet, om det samme ikke også kunne indvendes mod hans eget forsvarsskrift, hvori han skarpt angriber Faber, Mynster og Martensen. At han eventuelt også kunne komme til at skade sig selv, så han roligt i øjnene. Sandheden går forud for hensynet til egen person. Samlet konkluderer han:

Det endelige Resultat af disse Betragtninger bliver da dette: At den Maade, hvorpaa Pastor Grundtvig er gaaet frem i sit Forsvar for Baptisternes Religionsfrihed - selv under den Forudsætning, at det er fremgaaet af, om ikke agte, saa dog velmeente Bevæggrunde - ligesaalidt er skikket til at befordre den sande Christendom iblandt Menneskene, som deres Fard, der soge at haandhave den saakaldte Christendom ved paa en uchristelig og voldsom Maade, at udrydde og undertrykke det, som de ansee stridende derimod (Eiríksson 1844, 137 f.).

I sin kritik af Grundtvig underkendte Eiríksson helt de bevæggrunde, denne har haft til at udgive sin pjece. Det havde langtfra været Grundtvigs intention at forsvare baptismens dåbsopfattelse eller dens administration af nadveren, men derimod baptisternes ret til sognebåndsløsning, udtrædelse af statskirken og dannelse af en frimenighed. Som Eiríksson fastholdt sin opfattelse af den kristne dåb som en voksendåb, der forudsætter tro, og på dette punkt var enig med baptisterne uden dog at slutte sig til dem, ${ }^{25}$ fastholdt Grundtvig sin, ifølge hvilken barnet ved dåben bliver et Guds barn, og hvor Eiríksson afviste, at dåben og nadveren er sakramenter (f.eks. Eiríksson 1844, XVII), var dåben og nadveren for Grundtvig de piller, på hvilke hans kirkesyn byggede. Det synes at være spilfægteri fra Eiríkssons side at forlange, at for at være ægte skal et forsvar for retten til fri religionsdyrkelse bygge på en anerkendelse af en religiøs overbevisning, som afviger fra ens egen. Så hårdt, som Eiríksson på skrift angreb Myn-

${ }^{25}$ I sit lille erkendelsesteoretiske skrift Tro, Overtro og Vantro i deres Forhold til Fornuft og Forstand samt til hinanden indbyrdes (1846) omtalte Eiríksson i indledningen sit forhold til baptisterne. Han skriver her, at det er en fejltagelse at tro, at han er baptist; thi "[i]kke engang fra først af har jeg været fuldkommen tilfreds med deres religiøse Anskuelser og reformatoriske Bestræbelse" (Eiríksson 1846, XII) og tilføjer uddybende: "[J] eg mener: at deres Afvigelser [fra Kirkens lære] ikke er tilstrækkelige eller fundamentale nok” (XIII). Baptisterne var for Eiríksson ikke radikale nok. 
ster, Faber og Martensen, tyder intet på, at han selv opfyldte det krav, som han stillede til Grundtvig.

Eiríksson havde slet ikke øje for, at det, der drev Grundtvig i hans forsvar for baptisterne, var den klippefaste overbevisning om, at troen er et samvittighedsanliggende, og at samvittighedsfrihed - som Grundtvig i 1834 skrev i Den danske Stats-Kirke upartisk betragtet - "baade er al Religjons øverste Grund-Sætning og enhver ustraffelig Borgers utabelige Ret" (US 8, 57). Selv om han var uenig med baptisterne, burde de ifølge hans opfattelse som andre såkaldte kættere "faae Lov til at føre baade theoretiske og praktiske Beviser for deres Religjons Sandhed og Gavnlighed” (US $8,59)$.

Eiríksson kritiserede i sin bog ikke særskilt Grundtvigs dåbsopfattelse, men i sin klassifikation af danske teologers lære om dåben indregner han Grundtvig blandt klassen af "de craskirkelige og speculative Theologer", som er den første hovedklasse "ikke fordi den er den vigtigste, men fordi den indeholder den største Forvirring og de allerstørste Vildfarelser" (Eiríksson 1844, 528, note ${ }^{*}$ ). Denne klasse har fire underafdelinger, hvoraf den første udgøres af Faber og Martensen, den anden af pastor Daumgaard, den tredje af P.A. Adler og den fjerde af Grundtvig og hans tilhængere,

der ad den cras-kirkelige, katholiserende Vei nærmer sig til de to store Anførere [Faber og Martensen], og i visse Dele stemmer overeens med dem; men hans [dvs. Grundtvigs] er ikke saa consequent og systematisk gjennemført som deres, og han mangler derfor flere vigtige Puncter, hvori han med Hensyn til den systematiske Forkeerthed og Vildfarelser stader tilbage for Biskop Faber og Prof. Martensen (Eiríksson 1844, 529).

En noget betinget ros!

Ved betegnelsen "cras-kirkelig" forstod Eiríksson nærmest "udpræget eller ensidigt kirkelig" eller "traditionelt kirkelig". For Grundtvigs vedkommende må det antages, at hans fastholden ved den danske statskirkes traditionelle ritual i Eiríkssons øjne har gjort hans dåbsopfattelse "craskirkelig". 


\section{Eiríkssons opgør med skriftteologien}

Efter 1844 og frem til 1852 skrev Eiríksson adskillige større og mindre afhandlinger og avisindlæg. Tre af de mindre afhandlinger eller stridsskrifter var rettet imod H.L. Martensen, som blev angrebet overmåde barskt. Der fandtes hos Martensen, hævdede Eiríksson, talrige ureligiøse, ukristelige og fejlagtige opfattelser, og han burde afsættes fra sit professorat, da han ved at påvirke de studerende, der søgte hans auditorium, kunne skade dem åndeligt. Eiríkssons ordvalg og ikke mindst den kritik af Mynster, som han ved samme lejlighed fremførte, suppleret af en henvendelse til kongen Christian 8., resulterede $\mathrm{i}$, at myndighederne pålagde generalfiskalen, dvs. statsmagtens øverste anklager, at rejse sag imod ham. Sagen bortfaldt dog i kraft af det almindelige amnestidekret i forbindelse med Frederik 7.s tronbestigelse i 1848.

Fra 1852 og ti år frem var Eiríksson stort set tavs. Da han i 1863 igen fortsatte sin skribentvirksomhed, var han ikke længere skriftteolog. Selv skriver han i sin redegørelse fra 1875 om sin forfattervirksomhed, at

da jeg nu engang var kommet ind paa Undersøgelsens og Opdagelsens Vei, da jeg ærligt og oprigtigt søgte Sandhed, uden Hensyn til materiel Fordel, kom jeg i denne Tid [dvs. mellem 1852 og 1863] efterhaanden til at betragte Skriften paa en anden Maade end før, til at betragte den som en Bog, der vel indeholder de høieste og vigtigste Sandheder, men hvor der dog samtidig findes en stor Mængde Feil og Vildfarelser, Misforstaaelser og Modsigelser (selv i meget vigtige Ting) samt Uvidenhed om Naturen og dens Love; altsaa som en Bog, hvor Klinten maa skjelnes fra Hveden, hvor Alt maa prøves og undersøges, for at det Feilagtige og Falske ikke skal sammenblandes med, forvirre og fordunkle det Sande og Rette (Eiríksson 1875, 100).

Eiríksson havde som teologistuderende overværet H.N. Clausens forelæsninger over bibelsk eksegese, som han senere roste som "fortrinlige exegetiske Collegier" (Eiríksson 1844, VII). Efter sin teologiske attestats i 1837 virkede han i en årrække som en meget søgt manuduktør i gammeltestamentlig og nytestamentlig eksegese, men efterhånden som hans radikale syn på kristendom og kirke blev kendt, svandt hans tilhørerskare ganske betydeligt ind. Efter opgøret med Martensen i sidste halvdel af 1840 'erne 
intensiverede han sine eksegetiske studier, og i 1863 fremlagde han resultatet i bogen: Er Johannes-Evangeliet et apostolisk og agte Evangelium og er dets lare om Guds Menneskevorden en sand og christelig Lare? En religiøsdogmatisk, historisk-kritisk Undersøgelse.

Allerede i slutningen af det 18. århundrede og i de første tiår af det 19. var Johannesevangeliets ægthed blevet draget i tvivl, men angrebene på evangeliets apostolske ægthed fik først substans, da den tyske rationalistiske teolog Karl Gottlieb Bretschneider (1776-1848) i 1820 udgav sin Probabilia de evangelii et epistolarum Johannis apostoli indole et orgine (Sandsynlige teser om beskaffenheden af og oprindelsen til apostlen Johannes' evangelium og breve). Bretschneider argumenterede her blandt andet for - med H.N. Clausens ord - at

Evangeliet er skrevet i det andet Aarhundrede af en Hedninge-Christen, der i apostolisk-polemisk Hensigt har benyttet Johannes's Navn, for saameget kraftigere at kunne føre Evangeliets Sag imod Jøderne, som efter deres Stats Undergang saae sig nødsagen til at skifte Vaaben imod de Christne, istedetfor Vold og Forfølgelse stillede Bagvadskelser og Fordreielser (Clausen 1855, 351).

Bretschneiders bog gav anledning til en voldsom strid i tysk teologi, hvori blandt andre Schleiermacher og den kontroversielle David Friedrich Strauss (1808-74) deltog. Yderligere historisk-kritiske grunde mod evangeliets ægthed blev fremsat af førende tyske teologer som Wilhelm Martin Leberecht de Wette (1780-1849) og den såkaldte Tübingenskoles leder Ferdinand Christian Baur (1792-1860). Eiríksson studerede dem alle og syntes stort set at have tilsluttet sig den opfattelse, som f.eks. de Wette var talsmand for, nemlig at Johannesevangeliet ikke var skrevet af apostlen, men muligvis af en aposteldiscipel, og at det i forhold til de synoptiske evangelier var et relativt sent, anti-jødisk og hellenistisk skrift påvirket af gnostisk mysticisme. ${ }^{26}$

I indledningen til sin bog om Johannesevangeliet skrev Eiríksson blandt andet:

26 Se Rogerson 1992, 244 f. 
Da jeg nu anseer det for min specielle Livsopgave at gjøre hvad der staaer i min Magt for at udrydde de farlige og fordærvelige Vildfarelser, som have indsneget sig i den christelige Religion, og ligefra de ældste Tider fyldt den med falske Læresætninger, og da jeg i den senere Tid er kommen til den overbevisning, at de falske Lardomme i det Mindste tildeels have deres Grund i de uagte Dele af Skriften, saa følger deraf ligefrem, at jeg har følt mig opfordret til at gjøre Begyndelsen med at undersøge og udtale min Overbevisning om det Skrift i det N.T. som er blevet urigtigt bedømt, og som efter min Mening nærmest er at betragte som Grunden til det falske kirkelige Laresystem. Dette Skrift er JohannesEvangeliet (Eiríksson 1863a, XXIX).

Mange stridigheder, meget had, mange forfølgelser, grusomheder og afskyeligheder, skriver Eiríksson, havde været undgået, hvis man i rette tid havde erkendt, at beretninger i Det Gamle Testamente om f.eks. skabelsen, syndfloden og Noas ark er urimelige, og at steder i Det Nye Testamente om f.eks. dåben ikke stammer fra Kristus, men er blevet udnyttet af det kirkelige hierarki til at forøge sin magt og håndhæve sin myndighed (Eiríksson 1863a, XIII og XV).

Denne miskreditering af Johannesevangeliet er der grund til at hæfte sig ved som endnu en modsætning til Grundtvig, for hvem netop dette evangelium spillede en afgørende rolle for hans kristendomsforståelse.

\section{Debatten i 1863 om grundtvigianismen}

Eiríksson havde i 1863 ikke kun travlt med at udgive sin bog om Johannesevangeliet, men nåede også at deltage i den diskussion af grundtvigianismen, som opstod samme år. Den umiddelbare anledning var, at Martensen d. 29. april 1863 havde holdt en ordinationstale med titlen "Apostlenes Inspiration" over en passage i Paulus' brev til galaterne, hvori der forekommer sætningen: "Men dersom endog vi, eller en Engel af Himmelen prædiker Eder Evangelium anderledes, end vi have prædiket Eder det, han være en Forbandelse!” (Gal 1,8). Rygtet gik i København, at Martensen ikke mindst havde hentydet til Grundtvig og hans lære. Da talen udkom 
ret hurtigt efter, at den var holdt, ${ }^{27}$ læste Grundtvig den, men kunne ikke se, at den indeholdt noget angreb på ham, hvilket han nævnte i en artikel i Dansk Kirketidende (Grundtvig 1863).

Da grundtvigianismen efterhånden af de ledende teologer blev set som en magtfuld bevægelse i det kirkelige liv i Danmark, greb både H.N. Clausen og H.L. Martensen den tilsyneladende lidt tilfældige anledning til for offentligheden at fremlægge deres indvendinger imod Grundtvig og hans tilhængere (Clausen 1863; Martensen 1863). ${ }^{28}$ Også Magnús Eiríksson blandede sig i koret (Eiríksson 1863b). Andre udgav også deres bidrag til diskussionen i form af pjecer og avisindlæg, nogle angreb Grundtvig, andre forsvarede ham, men de tre nævnte var hovedaktørerne.

Men det var nu ikke helt tilfældigt, at både Clausen, Martensen og Eiríksson fandt anledning til at kritisere Grundtvig og grundtvigianismen. Grundtvig havde i sin artikel i Dansk Kirketidende lidt provokerende udtrykt undren over, at "de Lutherske Høilærde i Danmark" selv efter "en heel Menneske-Alder ikke [har] fattet den soleklare Forskiel mellem Tale og Skrift, Ord og Bogstav [...]" (Grundtvig 1863b, sp. 349), skønt allerede Luther havde lært

at 'Ordet og Troen' udretter ved den Helligaand hele Guds Gerning i Mennesket, og at det hverken er ved Lasning eller ved Bøn og Faste, men ved Daaben og Nadveren efter Herrens egen Indstiftelse, at de Troende gienfodes til Guds Børn og mattes til et evigt Liv i Christus Jesus.

Når derfor Grundtvig lærer,

at det er Indstiftelsens Ord af Herrens egen Mund, der, som et kiærligt og almægtigt Guds-Ord, baade gienfoder og himmelsk opfoder de Troende til aandeligt og hjerteligt Fallesskab med Vorherre Jesus Christus om hans guddommelige Menneske-Liv (Grundtvig 1863b, sp. 355 f.),

Talen blev genoptrykt i Martensen 1868, 82-97.

28 I dogmatisk henseende er Martensens skrift kun en uddybning af, hvad han allerede tidligere har skrevet i anmærkninger til \$ 23 i Den christelige Dogmatik fra 1849 (Martensen 1849). 
kan det ikke, mente han, være i strid med den lutherske opfattelse.

Clausen tog i sit indlæg handsken op og forsøgte at vise, at Grundtvigs opfattelse af forholdet mellem de "levende" ord, der lyder ved sakramenterne, og Skriftens "døde bogstaver" var i strid med evangelisk-luthersk opfattelse. Ud fra Grundtvigs artikel og den serie af artikler, som Grundtvig offentliggjorde fra 1855 til 1861 i tidsskriftet Kirkelig Samler. Tidsskrift til christelig Oplysning, der i 1868 udkom samlet under titlen Den christelig Børnelardom, karakteriserede han grundtvigianismen i fem punkter: (1) Skriften er uundværlig for den kristne forkyndelse; (2) dog virker ånden ikke på mennesket gennem skriftordet, (3) men ved de ord af "Herrens egen Mund", der, som det fremgår af Det Nye Testamente, lød ved indstiftelse af dåb og nadver, (4) og i forening med Den Apostolske Trosbekendelse, som igennem århundreder har været grundlaget for Kristi Kirke. Den forening havde Grundtvig kaldt for sakramentordet. Kun dette ord (5) har den levende indflydelse på den troende, som skriftordet mangler. Herefter kan Clausen resumere, at den grundtvigske anskuelse går ud på, at "Imellem Skriftordets og Sacramentsordets Betydning og Kraft skal der være en himmelvid Afstand, som nærmer sig stærkt til Modsætning” (Clausen 1863, 12)..$^{29}$

Efter at have anført en række citater fra reformatorerne og katolske autoriteter konkluderede Clausen, at Grundtvigs opfattelse af forholdet mellem sakramentord og skriftord var i strid med den luthersk-evangeliske opfattelse af forholdet, men i fuld overensstemmelse med den katolske. Han kan da polemisk afslutte sit indlæg med bemærkningen om, at mon ikke den katolske propagandakongregation,

som er langt fra at opgive Nordens Lande, skulde taknemmelig paaskjønne den foreløbige Cultivering af den Kirkelige Jordbund, hvorved Nedlægning af den romerske Sæd vil være forberedt til en lovende Høst? Dette betænke man vel og betænke itide! (Clausen 1863, 52 f.).

Både her og i erindringerne udtalte H.N. Clausen skarp kritik af Grundtvig og hans tilhængere, men han anerkendte fuldt ud Grundtvigs frisind

29 Grundtvig havde i digtet "Guds-Ordet til os", som er trykt i Dansk Kirketidende umiddelbart før hans artikel, skrevet de i tiden ofte citerede strofer: "Kun ved Badet og ved Bordet / Hører vi Guds Ord til os" (Grundtvig 1863a, sp. 346). 
og poetiske kraft. I et lille skrift fra 1862 om sognebåndet skrev han om grundtvigianerne:

Og selv med de hyppige, til det Parodiske grænsende, Exempler paa Smagløsheder af mangfoldig Art, affecteret Naivitet, manieret Barnlighed, opskruet Bersærkervæsen for Øie, kan det ikke miskjendes, hvor meget af den frie, friske, tiltalende Naturlighed der fra denne Kilde er kommet ind i dansk Prædiken og Psalme, i Kirkesang og Ungdoms-Underviisning, som velgjørende Modvægt imod det Stivstøbte, det i kunstlet Regelrethed Forpiinte (Clausen 1862, 43).

I modsætning til Mynster, som kun havde set Grundtvig og hans tilhængere som et uroelement i dansk kirkeliv, kunne Clausen trods den indledende barske kritik dog også sige nogle anerkendende ord om sin gamle kirkelige og personlige modstander.

Også Martensen havde i sit Til Forsvar mod den saakaldte Grundtvigianisme (1863) pæne ord at sige om Grundtvig som en væsentlig skikkelse i dansk kirkeligt liv, skønt han ikke kunne anerkende ham hverken som teolog eller som reformator. Med en metafor, som var yndet i datiden, sammenlignede han grundtvigianismen, som den fremtræder i praksis, med en surdej, der har tilført det kirkelige liv meget, der både havde været til glæde for Martensen selv og for andre:

Fordi jeg i Grundtvigianismen ikke kan erkjende noget nyt kirkeligt Princip, det vil sige, et nyt Første, hvoraf en Mangfoldighed af frugtbare Følger kan fremvoxe, kan jeg meget vel i denne erkjende et Ferment, en kraftig Suurdei. Og fordi jeg i een Henseende betragter den som en Suurdei, der maa udrenses, kan jeg meget vel i andre Henseender betragte den som en Suurdei, der velgjørende har gjennemtrængt den danske Kirke (Martensen 1863, 91). ${ }^{30}$

Når Martensen udtalte sig om Grundtvig og grundtvigianismen, var det på et andet grundlag end H.N. Clausen. Skønt det ikke fremgår af hans

\footnotetext{
30 Martensens lille skrift mod Grundtvig, som er et af Martensens bedste, blev meget læst. I udgivelsesåret udkom yderligere fire oplag, et sjette udkom så sent som i 1874 .
} 
erindringer, hvor det personlige fylder ganske lidt og aldrig uddybes, var Martensen i et par ungdomsår, før den filosofiske interesse greb ham, i tæt kontakt med en række af de unge, der samledes omkring Grundtvig, og det i den grad, at han ifølge kirkehistorikeren J. Oskar Andersen i denne periode af sit liv må kaldes grundtvigianer. ${ }^{31}$

I lighed med Clausens skrift mod grundtvigianismen var også Martensens fremprovokeret af Grundtvigs kritik af de "Lutherske Høilærde i Danmark" for endnu ikke at have fattet det rette forhold mellem "det levende Ord” og "det døde Bogstav". Og Martensen var i sit svar på provokationen ikke mindre provokerende, idet han meget omhyggeligt viste, at Grundtvigs “mageløse” opdagelse slet ikke var så mageløs, som ophavsmanden og hans tilhængere hævdede, idet Lessing 50 år før Grundtvig havde gjort den samme opdagelse og til og med havde udkastet den hypotese, som også Grundtvig og flere af hans tilhængere hældede til, at Kristus havde belært sine disciple om Den Apostolske Trosbekendelse i perioden mellem opstandelsen og himmelfarten. Også Grundtvigs modstillen af "det levende Ord” og "det døde Bogstav" fandtes hos Lessing. Lidt ironisk skrev Martensen, at han ved at fremlægge de i og for sig kendte oplysninger om Lessing, "ingenlunde frygter [...] at være traadt Grundtvigs Originalitet for nær" (Martensen 1863, 24). Martensen var selvfølgelig klar over forskellen imellem Grundtvig og Lessing, som havde udviklet sine synspunkter om det mundtlige ord i en polemik imod en skriftteologi, der betragtede hvert ord i Skriften som inspireret, og hvis forhold til kristendommen langt fra var det dybe og inderlige som Grundtvigs.

Argumentet for, at den apostolske trosbekendelse havde foreligget før evangelierne, var også, mente Martensen, det samme hos Lessing og Grundtvig. Der er intet historisk belæg for sagen, men argumentet er et apriori argument. Hvis dåben er guddommeligt indstiftet, må formuleringen af de salighedsbetingelser og vilkårene for at blive optaget i den kristne kirke, som fremgår af Den Apostolske Trosbekendelse, have samme kilde. Derfor må den apostolske trosbekendelse være gået forud for evangelierne. Kritikken af argumentet for ud fra en begrebsmæssig nødvendighed at slutte til virkelighed havde Martensen allerede fremsat i sin dogmatik fra 1849 (47 f.). Martensen nævner også i sit forsvar vanskeligheden med så at

${ }^{31}$ Andersen 1933, 183. På dette punkt byggede J. Oskar Andersen på Frederik Hammerich (Hammerich 1882, 186 ff.). 
forklare, hvorfor den apostolske trosbekendelse ikke er omtalt i Det Nye Testamente. Og nok er troen på Jesus og den treenige gud fundamentale salighedsbetingelser, men det er umuligt, mener Martensen, at fastslå, at det er de eneste. Ligesom ingen kan sige, hvad der skal til, for at leve et moralsk liv, kan ingen sige, hvor langt guddommens krav til mennesket rækker.

Martensen understreger også, at grundtvigianernes tale om en dåbspagt er misvisende:

For det Første er det en Misviisning saa godt som udelukkende at lade Daabsbekjendelsen være Daabspagten, da den dog kun er Kirkens Vidnesbyrd om en Deel deri, nemlig om Forpligtelsens Moment i Pagten som den ogsaa er den vordende Christnes Tilslutning til dette Vidnesbyrd. Men Daabspagten er først og fremmest en Naadepagt som Herren slutter med os [...]. Men dernæst er det en Misviisning at opfatte Forpligtelsen som Forpligtelse til et vist Indbegreb af Sætninger, men ikke først og fremmest til det som er Enheden og Aanden i disse Sætninger (Martensen 1863, 32 f.).

For Martensen var Grundtvigs teologi dårlig teologi. Og den anerkendelse, der hos Martensen blev Grundtvig til del, var også kun en behersket anerkendelse. Martensen sluttede nemlig sit forsvar med at pege på, at tidens store opgave var at forene det kristne og det humane - hvilket var, hvad både Mynster og Martensen forsøgte i hver deres form for formidlingsteologi, og som Kierkegaard afviste var muligt - men hos Grundtvig blev det kun til en uklar og ukritisk sammenblanding af det kristne og det folkelige.

Det var typisk for Martensen både at anerkende og trække sin anerkendelse tilbage. Hans stillingtagen var sjældent knivskarp, men ofte et bådeog og derfor uklar. Eller som Kierkegaard - det personificerede "enteneller" - så rammende sagde: "Med Martensen vilde jeg aldrig indlade mig uden at have Notarius publicus med, for dog at faae Noget til at staae fast" (SKS 22, 187). 


\section{Eiríkssons kritik af Grundtvig og grundtvigianismen}

Eiríkssons anledning til at komme med sit udfald imod Grundtvig og hans tilhængere synes ikke at have været Grundtvigs provokation i artiklen om "Lys-Ordet og Livs-Ordet" (1863), men snarere, at hans yndlingsfjende Martensen, som efter Eiríkssons opfattelse ved sit filosofisk-spekulative perspektiv på kristendommen havde forfalsket dens oprindelige enfoldige lære, havde ytret sig om grundtvigianismen. Eiríkssons indlæg mod Grundtvig var derfor også et indlæg mod Martensen. Spørgsmålet om, hvorvidt Grundtvig eller Martensen har ret i deres opfattelse af kristendommen, besvarede han ved at forsøge at vise, at begge på nogle punkter har ret, på andre uret, og at begge parter gjorde sig skyldig i de samme vildfarelser og forvanskninger af den oprindelige kristendom, som den var blevet formidlet af Kristus til apostlene og var kommet til udtryk i Den Apostolske Trosbekendelse.

Eiríksson var langt den mest radikale af grundtvigianismens kritikere i det 19. århundrede. Martensen havde i sit indlæg mod Grundtvig og hans kreds understreget, at det

[h]eller ikke maa glemmes, men stadigt fastholdes, hvad ogsaa ved flere Leiligheder er indrømmet fra den Grundtvigske Side, at den hele Strid dog er indenfor det Christelige, og ingenlunde en Strid mellem det Christelige og Antichristelige, og heri ligger dog vel Muligheden til en nærmere Forstaaelse, om ikke for Tiden, saa dog med Tiden, hvis Ildprøve Alt desuden har at gjennemgaae (Martensen 1863, 4).

Hverken Martensen eller Grundtvig svarede nogen sinde Eiríksson. De har utvivlsomt ment, at han stod uden for det kristelige, idet han ikke alene afviste barnedåben, men også treenighedsdogmet og dogmet om Kristi guddommelige natur (to-naturlæren). Med ham var intet fællesskab muligt. Derfor var enhver diskussion med ham formålsløs.

Eiríkssons lille skrift vendt mod grundtvigianerne, Hvem har Ret: Grundtvigianerne eller deres Modstandere? Og Hvad har Christus befalet om Daaben? Nogle orienterende Bemarkninger, (Eiríksson 1863b) er opdelt i fire afsnit. I det første diskuterer han, om dåben i treenighedens navn og Den Apostolske Trosbekendelse kan tilskrives Kristus, og i det andet analyserer han forholdet mellem det ældste apostolske symbol og de to 
senere, nemlig det nikænske og det athanasianske. Herefter følger et tredje afsnit, hvori han diskuterer grundtvigianismens forhold til den lutherske reformation, og han afslutter med et afsnit om det, som han betragter som hovedsagen for grundtvigianerne, nemlig modsætningen mellem "det levende Ord" og "det døde Bogstav".

Grundtvigianernes opfattelse af dåbsritualet og hermed også den apostolske trosbekendelse som "Herrens Mundsord" er, mener Eiríksson, deres grundvildfarelse. Ifølge Matt 28,19 skulle Kristus have sagt til sine disciple: "Gaaer derfor hen, og lærer alle Folk, og døber dem i Navnet Faderens, og Sønnens, og den Hellig Aands”, og ifølge Mark 16,15: "[G]aaer bort i al Verden, og prædiker Evangelium for al Skabningen." Hvis det kan vises, skriver Eiríksson, at Kristus ikke har befalet eller ikke kunne have befalet noget sådant til sine disciple, kan hverken dåben i treenighedens navn eller den apostolske trosbekendelse henføres til ham. Og det mener Eiríksson at kunne, eftersom der i Apostlenes Gerninger nævnes adskillige eksempler på dåb, der ikke er foretaget i treenighedens navn (f.eks. ApG 8,29-37, hvor der døbes, fordi dåbsbarnet tilkendegiver, at han "troer, at Jesus Christus er Guds Søn", ApG 10,48 og ApG 19,2-6, hvor der i begge tilfælde døbes i Kristi navn). Endvidere må "alle Folk" i Matt 28,19 og "al Skabningen" i Mark 16,15 omfatte såvel jøder som ikke-jøder, men i ApG 10 og 11 angribes apostlen Peter af omvendte jøder for også at omgås og døbe ikke-jøder, og Peter henviser da til, at han har modtaget en speciel åbenbaring, hvori han pålægges at gøre begge dele. Har disciplene da så hurtigt efter Kristi opstandelse glemt hans befalinger, og hvorfor skulle det, som Peter tidligere har fået befaling til at gøre, åbenbares ham? Det mest rimelige er at antage, at Kristus aldrig har befalet som hævdet i Matthæus- og Markusevangeliet, og at de pågældende steder er uægte. Herefter kan Eiríksson konkludere:

Men har Christus ikke givet nogen Befaling om Daaben, og specielt ikke sagt de Ord, som findes i Matth. 28,19, saa er det klarere end Dagen, først: at den grundtvigianske Lare om "det levende Ord af Herrens egen Mund", om "det evige Livs (!) Ord af vor Herres egen Mund" osv. er bygget paa Sand, er en reen Phantasi, og dernæst: at Kirkens Daab " $i$ Navnet Faderens og Sønnens og den Hellig Aands" ikke er befalet af Christus, siden hans egne troe og lydige Apostle, som hvert Øieblik vare beredte til at opoffre deres Liv for at udbrede Christi Lære og udføre 
hans Befalinger, ikke kjende det Mindste til denne Befaling, eller omtale den med et eneste Ord, skjønt der saa ofte var Leilighed og Opfordring til anvende og omtale den (Eiríksson 1863b, 19 f.).

Når Eiríksson mener at have belæg for, at dåbsbefalingen i Det Nye Testamente er uægte, er det en noget forhastet slutning, idet han forudsætter, at beretningerne i Apostlenes Gerninger er ægte. Den eneste holdbare konklusion, han kan drage, er den yderst velkendte, at der er steder i Det Nye Testamente, som er vanskelige at forene.

$\mathrm{Nu}$ ville Eiríkssons manipulation med "døde Bogstaver" næppe have afficeret grundtvigianerne, og det var måske snarere Martensen, han havde for øje, idet denne nok mente, at den kirkelige tradition kunne belyse Skriften, men ikke, at traditionen var kriteriet på Skriftens sandhed. Snarere forholdt det sig omvendt.

Dernæst gælder det forholdet mellem Den Apostolske Trosbekendelse og de to yngre trosbekendelser. Hvor Martensen og hans tilhængere traditionelt betragtede Den Nikænske og Den Athanasianske Trosbekendelse som vigtige, tillagde Grundtvig og hans tilhængere dem ikke videre vægt. Men begge disse bekendelser er led i kirkens historie og er derfor, måtte Martensen mene, i lighed med Den Apostolske Trosbekendelse elementer i "den store Tilegnelsesproces af den christelige Aabenbaring" (Martensen $1863,79)$. Dette betyder, at de to senere trosbekendelser kun er uddybninger af, hvad der er indeholdt i den apostolske. Denne "høiaandelige martensenske Betragtning af Kirkens Historie" tilskriver Eiríksson det hegelianske islæt i Martensens teologi (Eiríksson 1863b, 22) og henviser til Martensens lille moralfilosofiske kompendium fra 1841, hvor forfatteren nævner "Hegels bekjendte Fordring, at man skal erkjende det Virkelige som det Fornuftige [...]" (Martensen 1841, 57). ${ }^{32}$ Det giver Eiríksson rig anledning til at harcelere over, at så må Martensen også mene, at "al den grændseløse Forkeerthed og Fordarvelse, Udvorteshed og skinhelligt Hykleri, aandeligt Mørke og Vildfarelser, Trældom og Barbari, Forfølgelse og Fanatisme" sammen med "alle Inqvisitionens Rædsler, Tortur og Henrettelser af Uskyldige i Tusindeviis", som kirkehistorien vidner om, hører til "den store Tilegnelsesproces af den christelige Aabenbaring” (Eiríksson 1863b, 23).

32 Jf. Hegels ofte citerede ord i Grundlinien der Philosophie des Rechts, "Was vernünftig ist, das ist wirklich; und was wirklich ist, das is vernünftig" (Hegel 1970, 7). 
Grundtvigianerne, mener Eiríksson, har ret i at tilsidesætte de to yngre trosbekendelser, men de har ikke den egentlige grund til at gøre det, og Martensen har uret, når han mener, at de er videreudviklinger eller udlægninger af første trosbekendelses åbenbaringsindhold. I denne findes intet om treenigheden, intet om Kristi to naturer, og Kristus fremtræder kun som Messias, dvs. som den forventede konge og befrier for det romerske åg, og ikke, som i de to senere trosbekendelser, som en guddom, der har eksisteret fra evigheden af, alt sammen dogmer, som således må anses for at være i strid med den oprindelige enfoldige kristendom. Årsagen til disse ukristelige og falske afvigelser fra den rene lære skyldes filosofi og dialektik og ikke mindst de religiøse stridigheder, som udspandt sig i oldkirken. Eiríksson var enig med såvel Grundtvig som Søren Kierkegaard i, at den såkaldte videnskabelige teologis forsøg på at forstå den kristne religions mysterier ved hjælp af filosofiske kategorier var dømt til at føre til fejlagtige og ikke-kristne anskuelser.

Herefter kan Eiríksson konkludere:

De, som nu have en saa vild Indbildningskraft, at de kunne overtale sig selv til at troe: at de omtalte Symboler fra det 4de og 5te Aarhundrede, "kun ere Udlægninger og nærmere Forklaringer af det apostoliske Symbolum" have sikkert ikke Noget at lade Grundtvigianerne høre om "Illusioner" og tomme Indbildninger; thi er den saakaldte "nye Opdagelse": at hele den apostoliske Troesbekjendelse er meddelt Apostlene af Jesus Christus selv i Tiden mellem Opstandelsen og Himmelfarten, en tom Indbildning og Illusion — og det er den visselig - saa er den nysnævnte Betragtning af "de efterfølgende Troesbekjendelser" og deres Forhold til den apostoliske det ikke mindre. Og spørge vi: hvilke af disse to Illusioner eller Indbildninger er den farligste, saa troe vi vel, at der nok kunne være forskjellige Meninger derom; men vi skulde dog tage meget feil, om den martensenske Illusion ikke var den farligste; thi vel faaer det apost. Symbol en aldeles overdreven Vægt og Betydning derved, at den henføres til Christus selv og betragtes som det eneste "levende og levendegjørende Ord" i Modsætning til "det døde Bogstav; men da det apostoliske Symbol indeholder den oprindelige eenfoldige Lære, [...], kan denne Overdrivelse af dets Værd og Betydning neppe nogensinde blive saa skadelig som en halvspeculativ eller quasi-orthodox Kulsviertro paa Symbolers 
Ægthed, der aabenbart indeholder en aldeles falsk og uchristelig Lære, en Lære, som Christus og Apostlene ikke kjende noget til (Eiríksson 1863b, 40).

Efter denne bombastiske konklusion, som giver et indtryk af Eiríkssons polemiske sprogbrug, vender han sig mod det, der var H.N. Clausens hovedanliggende, nemlig grundtvigianismens forhold til den lutherske reformation. Hans konklusion bliver her, at Grundtvig nok er protestant, men i en noget anden betydning, end reformatorerne var det.

Clausen var i sin pjece nået frem til den konklusion, at grundtvigianismen ikke er en fortsættelse af den lutherske reformation, men en reform af den, "en ny Grundlægning til en ny Kirkebygning" (Clausen 1863, 9).

En væsentlig forskel mellem Luther og Grundtvig var, at Luther i sin søgen efter den sande kristendom kun gik tilbage til kirkefaderen Augustins lære om synd og nåde; men Luther skulle være søgt meget længere tilbage, til Irenæus (2. årh.), som gennem sin læremester Polykarp repræsenterede en tradition, der direkte kunne føres tilbage til kredsen omkring apostlen Johannes og derfor til den apostolske tidsalder. Efter at gjort sin "mageløse opdagelse" fik Irenæus stor betydning for Grundtvig, der betragtede Irenæus' bog mod kætterne (Adversus haereses), dvs. gnostikerne, som "den christeligste Bog", han kendte, idet den vidnede om "Troens Ord ved Daaben". ${ }^{33}$

Eiríksson pegede også på en anden forskel mellem Luther og Grundtvig, idet dennes tilbagegang til apostolsk tid havde reduceret Skriftens betydning, hvorimod Luther over for den katolske kirkes autoritetsprincip havde hævdet skriftprincippet. Og hvor Grundtvig lagde uhyre vægt på den apostolske trosbekendelse, fremhævede Luther også den nikænske og athanasianske.

Der er dog den lighed mellem Luther og Grundtvig, at de begge hylder treenighedsdogmet, hvorom intet findes i den apostolske trosbekendelse, og begge tror på dåbens mirakuløse virkning, hvilket ikke mindst skyldes, at de ikke har holdt sig til de synoptiske evangelier, men også er overbevist om Johannesevangeliets ægthed, og har tilsluttet sig de teologiske

33 Se Grundtvigs forord til 2. udgaven af hans oversættelse fra 1827 af femte bog af Irenæus' skrift, som i Grundtvigs oversættelse fra 1855 har titlen Om Kiødets Opstandelse og det evige Liv (Grundtvig 1855). 
spidsfindigheder, der blev udviklet i efterapostolsk tid. Dette er, mener Eiríksson, for Grundtvigs vedkommende inkonsekvent. Derfor må han konkludere, at Grundtvig i virkeligheden slet ikke er lutheraner, og at han "burde forkaste det lutherske (samt overhovedet det kirkelige) Dogmesystem, som er bygget på den senere, af Speculationer og dogmatiske Stridigheder fremgaaende kirkelige Udvikling, og som navnlig skriver sig fra det 4de og 5te Aarhundrede" (Eiríksson 1863b, 45). Derfor burde Grundtvig og hans kreds træde ud af kirken, hvilket de ofte har truet med. Men når de ikke har gjort det og har tilsluttet sig væsentlige dele af det traditionelle lutherske dogmesystem, opløser hele striden mellem grundtvigianerne og deres modstandere sig "i Røg og Damp":

Men saa gjøre rigtignok Grundtvigianerne rettest $\mathrm{i}$ at stikke Piben ind, thi Intet kan være mere uholdbart end en saadan Opposition, der alene grunder sig paa en Antagelse, der er blot og bar Indbildning eller "Illusion". [...] Som sagt, naar Grundtvigianerne ikke ville følge den Lære, som det af dem forgudede Symbol indeholder, eller de ikke kunne forstaae dets Indhold, saa gjøre de klogest i at forene sig med deres Modstandere og gjøre fælles Sag med dem mod Kirkens Fjender, for at de kirkelige Vildfarelser saameget desto kraftigere kunne blive forsvarede. Kunde da min Optræden bidrage Noget til at de forbrødredes med hinanden, ligesom Herodes og Pilatus blev Venner paa den Dag, Jesus blev dømt til Døden, saa havde jeg ikke arbeidet omsonst (Eiríksson 1863b, 48 f.).

Også Eiríksson kunne være en habil ironiker!

Eiríksson slutter afsnittet med nogle bemærkninger om forholdet mellem kristendom og folkelighed med henblik på Grundtvigs velkendte appel til det folkelige i modsætning til det lærde.

Hvis dette forhold betragtes nøgternt, så indser man, mener Eiríksson, at kristendommen med dens almenmenneskelige indhold er mere egnet til at underbygge det nationale, som han identificerer med det folkelige, end dette er til at støtte kristendommen, og han fortsætter:

Dersom altsaa Grundtv[igianerne] virkelig ere overbeviste om, at den kirkelige Udvikling er forfeilet, og at Kirkelæren lider af uchristelige og farlige Vildfarelser, saa maae de forst søge at bekjæmpe disse Vildfa- 
relser, og dernæst søge at gjøre den rette Opfattelse af Christendommen saa popular og "folkelig" som muligt. Men dette skeer sandelig ikke ved at bilde sig selv og Andre ind, at den apostoliske Troesbekjendelse er meddelt Apostlene af Christus selv mellem Opstandelsen og Himmelfarten, ved at gjøre denne Fabel "folkelig" og national, og ved at udlede deraf den grundløse og forkeerte Paastand, at dette er det eneste Guds Ord, det eneste "levende og levendegjørende Ord (Eiríksson 1863b, 50).

I det sidste afsnit i Eiríkssons stridsskrift diskuterer han modsætningen mellem "det levende Ord" og "det døde Bogstav".

Nok tilskrev Eiríksson Grundtvig en vis åndelighed, men der er, mente han, tale om en uægte åndelighed, idet Grundtvigs lære om det levende ord af Herrens egen mund er ren fantasi, da henførelsen af den apostolske trosbekendelses til Kristus både er urimelig og åndløs.

For det første peger Eiríksson på, at det er urimeligt at antage, at Kristus skulle have sagt om sig selv, at han er "opfaren til Himmels, siddende hos Gud Faders, almægtigste høire Haand” (Eiríksson 1863b, 52). Dernæst må Kristus have modsagt sig selv, hvis han i den apostolske trosbekendelse har befalet troen på "Kjødets Opstandelse", da han ifølge Matt 22,30 ("Thi i Opstandelsen skulle de hverken tage til ægte, ei heller bortgiftes; men de ere ligesom Guds Engle i Himmelen") fraskriver de opstandne "et kjødeligt Legeme”. På dette grundlag konkluderer Eiríksson:

Symbolets Lære om "Kjødets Opstandelse" er saaledes lige modsat Christi Lære i Evangeliet, som aabenbart bærer Sandhedens Præg, og det saameget mere, som Christi Udtalelse her sættes i Forbindelse med et meget interessant Forhold og udgjør Svaret paa et meget vanskeligt Spørgsmaal. Og dog skulde Jesus have meddelt Apostlene denne Daabsbekjendelse, der indeholder en ganske modsat Lære om Opstandelsen! Nei, lader os dog være Mennesker, d.v.s. Væsener med en Smule Tænkning og Fornuft (Eiríksson 1863b, 53).

Endelig, for det tredje, mener Eiríksson, at det i høj grad er usandsynligt, at Kristus har meddelt sine apostle noget så dogmatisk og formelt som Den Apostolske Trosbekendelse, der ovenikøbet på det tidspunkt, den blev meddelt, indeholdt oplysninger om kommende begivenheder, og som 
ydermere fra Kristi side skulle være ment som en formular, der skulle benyttes, til verden gik under.

Dette kan man umulig antage om Christus, naar man har et nogenlunde sundt og rigtigt Begreb om hele hans Optræden og Maade at være paa. Han var saa langt fra al Formalitet som Nogen vel kunde være. [...] hele hans Stræben gik ud paa at vække det aandelige Liv i Mennesket, og at føre ham nærmere til Gud, bringe ham til at dyrke Gud $i$ Aand og Sandhed; men Sligt opnaaes ikke ved staaende Formularer (Eiríksson 1863b, 53).

Den grundtvigske skelnen mellem det levende ord og det døde bogstav fandt Eiríksson også urimelig. Kristi hele lære gik ud på at elske Gud og næsten og at lade denne kærlighed påvirke forstand og vilje, dvs. komme til udtryk i handling. Den tørre dåbsformular kan ikke røre menneskets hjerte og gribe sjælen således

som saa mange af de andre Ord, Jesus taler til Disciplene, Folket eller Pharisæerne og de Skriftkloge, og som ved saa mange Leiligheder havde en gjennemgribende Virkning, fordi Guds Aand talede igjennem dem, fordi de angik "Guds Rige" navnlig saaledes som det viser sig i Mennesker ("Guds Rige er indeni Eder” [Luk 17,21]) og "Guds Retfærdighed”, betragtet i sin ideale Reenhed og i sin Modsætning til det vanhellige Sind. Der skal mere end en almindelige Phantasi til at antage og troe, at "Daabs-Ordet" kan virke Mere til Menneskets Aandeliggjørelse end andre Christi Ord, som saa ofte have viist deres velsignelsesrige Virksomhed paa Menneskets Aand og Hjerte [...] (Eiríksson 1863b, 58).

Også i Skriften, mente Eiríksson, hører mennesket Guds ord henvendt til sig. Også mange af skriftordene er "levende Ord". Hvilke af Skriftens ord, Guds Ånd taler igennem, må som altid hos Eiríksson være et anliggende for den af kærlighed til Gud og næsten gennemtrukne fornuft. Grundtvigafsnittet i bogen om baptismen fra 1844 og stridsskriftet fra 1863 indeholder Eiríkssons principielle og mest omfattende kritik af Grundtvig og grundtvigianerne, hvis opfattelse han betragtede som ren fantasi og som en farlig trussel i datidens Danmark mod den rene evan- 
geliske lære, selv om den ikke forekom ham så farlig som Martensens videnskabeliggørelse af teologien på et spekulativt grundlag. Men også i andre af sine værker end de to nævnte kritiserede han grundtvigianerne. To år efter nederlaget til prøjserne i 1864 udgav han et mindre værk med titlen Gud og Reformatoren. En religiøs Idee, hvori han blandt andet kritiserede Kierkegaard og Rasmus Nielsen, men hvori Grundtvig og grundtvigianerne også fik deres bekomst. Indledningsvis stillede han her spørgsmålet om, hvordan den reducerede danske nation kunne genvinde en større selvbevidsthed og styrke. Nogle, skriver han, vil henvise til, at dette skal ske ved udvikling af kilderne til materiel velstand, andre til en forøget udvikling af de demokratiske institutioner. Begge dele vil kunne bidrage til at udvikle en lille nations indre kraft og styrke, men det vigtigste og mest afgørende, mente Eiríksson, ville være, at der kom et opsving i det åndelige især på religionens område. Nogle vil hævde, at netop den grundtvigianske bevægelse ville kunne frembringe et sådant:

Men skjøndt Grundtvigianismen i visse Maader kan være interessant, og skjøndt man ikke kan nægte den en vis 'Friskhed' og 'Folkelighed', er den dog, netop på Religionens Omraade, altfor huul, holdningsløs og vildfarende til at kunne hæve Nationen paa et høiere aandeligt Trin (Eiríksson 1866, X).

Heller ikke Grundtvig selv ville kunne forårsage en åndelig vækkelse. Under nederlagets ydmygende og tyngende omstændigheder henfalder han til at synge om "det herlige Land, de yndige Øer, 'den maigrønne Lund, ved det deilige Sund' og slutter som saa: at 'den gamle af Dage' ikke kan lade et saa deiligt Land som Danmark i Stikken” (Eiríksson 1866, X). ${ }^{34}$ Det falder ham heller ikke ind, at "gjøre Folket opmærksom paa, at det kunde have godt af at holde sig mere til Gud" (XI). Eiríksson afviste også Grundtvigs "nationale Betragtningmaade", for den synes "at smage vel meget af en Art indbildt Retfærdighed, og en vis national Fordringsfuldhed ligeoverfor Vorherre. [...] En ultranational Sværmer frelser aldrig sin

34 De to Grundtvigcitater stammer fra digtet "Til Danmark", som Grundtvig offentliggjorde i sit tidsskrift Danskeren, 1848 [!], nr. 10 (US 9, 125). Det første ("den maigrønne Lund osv.") er vers 3-4 i første strofe, og det andet ("den gamle af Dage") er slutningsordene i hver strofe. 
Nation i Ordets egentlige, sande Forstand. Gr. har udspilt sin Rolle [...]” (XI). Og med klar adresse til både Grundtvig og skandinavismen fastslog Eiríksson, "at Nordens Aand er uddød" (XXXI).

Fem år senere hentydede Eiríksson i bogen Paulus og Christus fra 1871 uden navns nævnelse til grundtvigianerne og kaldte dem "Nutids-Farisæere og Sadducæere” (Eiríksson 1871, 68 f.). Så vidt er grundtvigianerne kommet "i fantastisk Indbildskhed, aandeligt Hovmod og selvforguderisk Selvbehagelighed", at han ikke tror sig "i Stand til paa en værdig Maade at skildre en saa eiendommelig aandelig Forrykthed” (Eiríksson 1871, 68 f.).

Eiríksson blev ikke med årene mildere stemt over for dem, som han betragtede som fjender af den oprindelige, enfoldige kristendom.

\section{Forkortelser}

US I-X Holger Begtrup (udg.) (1904-09), Nik. Fred. Sev. Grundtvigs Udvalgte Skrifter, I-X, København, Gyldendalske Boghandel Nordisk Forlag.

SKS 1-28 ved Niels Jørgen Cappelørn et al. (udg.) (1997-2012), Søren Kierkegaards Skrifter, København, Gad.

\section{Litteratur}

Verker af Grundtvig

- (1825), "Antignosticus, Geist des Tertullianus und Einleitung in dessen Schriften” (anm.) i Theologisk Maanedsskrift, bind 3, København, 248-278.

- (1842), Religions-Forfolgelse. En Stemme, København, Wahl.

- (1855), Om Kiødets Opstandelse og det evige Liv (1855), Kjøbenhavn, J.R. Møller.

- (1860), Christenhedens Syvstjerne. Et kirkeligt Sagakvad, Kjøbenhavn, Michaelsen og Tillge.

- (1863a), "Guds-Ordet til os", i Dansk Kirketidende, nr. 22. sp. 345-346.

- (1863b), "Lys-Ordet og Livs-Ordet i Vorherre Jesu Christo Menighed" i Dansk Kirketidende, nr. 22, sp. 347-58.

- (1871), Kirke-Speil eller Udsigt over den christne Menigheds Levnetsløb, København, Schönberg. 


\section{Verker af andre forfattere}

Andersen, J. Oskar (1933), "Biskop H.L. Martensens Ungdom” i Kirkehistoriske Samlinger, 6. rk, I, 130-237.

Bajer, Fredrik (1879), Klara-Rafael-Fejden, København, C.A. Topps Forlag.

Begtrup, Holger (1901), N.F.S. Grundtvigs kirkelige Syn 1825. En historisk Indledning, København, Schönberg.

- (1936), Grundtvigs danske Kristendom historisk fremstillet, bd. 1-2, København, Gad.

Biblia, det er: den ganske Hellige Skrifts Bøger (1825), Kjøbenhavn, Vaisenhusets Forlag.

Bretschneider, Karl Gottlieb (1820), Probabilia de evangelii et epistolarum Johannis apostoli indole et orgine, Lipsiae.

Brøchner, Hans (1843), Nogle Bemarkninger om Daaben foranlediget ved Professor Martensens Skrift "Den christelige Daab”, København, Philipsen.

Clausen, Henrik Nicolai (1825), Catholicismens og Protestantismens Kirkeforfatning, Lare og Ritus, København, Seidelin.

- (1855), Johannes-Evangeliet, Fortolket, København, Gad.

- (1862), Anvendelsen af Loven om Løsning af Sognebaandet, København, Gad.

- (1863), Skriftordet og "Det levende Ord". Bidrag til Vurdering af Grundtvigianismens Stilling til Evangelium og Evangelisk Kirke, København, Gad.

- (1877), Optegnelser om Mit Levneds og min Tids Historie, København, Gad.

Eiríksson, Magnús (1844), Om Baptister og Barnedaab, samt flere Momenter af Den kirkelige og speculative Christendom, København, Philipsen.

- (1846) Tro, Overtro og Vantro i deres Forhold til Fornuft og Forstand samt til hinanden indbyrdes, Kjøbenhavn, H.C. Klein.

- (1849), Speculativ Rettroenhed, fremstillet efter Dr. Martensens "christelige Dogmatik" belyst ved en Biskops Deeltagelse i en Generalfiskal-Sag, København, trykt hos J.S. Salomon.

- (1863a), Er Johannes-Evangeliet et apostolisk og agte Evangelium og er dets Lare om Guds Menneskevorden en sand og christelig Lare? En religiøs-dogmatisk, historisk-kritisk Undersøgelse, København, eget forlag.

- (1863b), Hvem har Ret: Grundtvigianerne eller deres Modstandere? Og Hvad har Christus befalet om Daaben? Nogle orienterende Bemarkninger, København, Thaarup.

- (1866), Gud og Reformatoren. En religiøs Idee. Samt nogle Bemerkninger om de kirkelige Tilstande, Dr. S. Kierkegaard og Forfatteren, København, Schubothe. 
- (1871), Paulus og Christus eller Pauli Lare om Retfardiggørelsen sammenlignet med Christi Lare om Syndsforladelsen, tilligemed nogle Bemarkninger om andre paulinske Lardomme m.M., København, eget forlag.

- (1875), "Min Forfattervirksomhed" i Flyvende Blade for Literatur, Kunst og Samfundsspørgsmål, 3. årgang, nr. 11-13, 81-83, 90-93, 100-104.

Faber, Nicolai (1842), De anabaptistiske Bevagelser i Danmark betragtet fra det christelige og kirkelige Standpunkt, Odense, Hempel.

Fibiger, Johannes (1898), Mit Liv og Levned som jeg selv har forstaaet det, København, Gyldendal.

Forhandlinger paa Det Fjerde Nordiske Kirkemøde i Kjøbenhavn Den 5., 6. og 7. September 1871 (1871), Kjøbenhavn, Den Gyldendalske Boghandel.

Fortegnelse over N.F.S. Grundtvigs Bibliotek, som bortsalges ved offentlig Auction Mandag d. 29. September 1873 [...] (1873), København, trykt i E.C. Løsers Bog- og Nodetrykkeri.

Hammerich, Frederik (1882), Et Levnetsløb, København, Forlagsbureauet.

Hegel, G.W.F. (1970), Grundlinien der Philosophie des Rechts (Werke in zwanzig Bänden), bd. 1-20, bd. 7, Frankfurt am Main, Suhrkamp.

Himmelstrup, Jens \& Møller, Jens (1970), Danske Forfatningslove 1665-1953, 2. udg., København, Schultz.

Immanuel, Theodor (1851), Breve til Clara Raphael, Kjøbenhavn, Reitzel.

Kierkegaard, Thorvald [Magnús Eiríksson] (1958), Magnús Eiriksson og Mary B. Westenholz. To Forkampere for Unitarismen i Danmark, (Særtryk af Protestantisk Tidende), København.

Koch, Carl Henrik (2017a), "Magnús Eiríksson and Philosophy” i Gerhard Schreiber \& Jon Stewart (red.), Magnús Eiriksson. A Forgotten Contemporary of Kierkegaard, København, Museum Tusculanum Press, 17-54.

- (2017b) “Magnús Eiríksson and Grundtvig” i G. Schreiber og J. Stewart (udg.), Magnús Eiriksson. A Forgotten Contemporary of Kierkegaard, København, Museum Tusculanum Press, 167-211.

Kong Christian den Femtis danske Lov (1929), København, Gad.

Langhoff, Johannes (red.) (1980), Den lutherske Bekendelse i dag, Aarhus, Aros.

Martensen, Hans Lassen (1841), Grundrids til Moralphilosophiens System. Udgivet til Brug ved academiske Forelasninger, København, Reitzel.

- (1843), Den christelige Daab betragtet med Hensyn paa det baptistiske Spørgsmaal, 2. opl., København, Reitzel.

- (1849), Den christelige Dogmatik, København, Reitzel. 
- (1863), Til Forsvar mod den saakaldte Grundtvigianisme, København, Gyldendal.

- (1868), Taler ved Prestevielse, holdte i Aarene 1860 til 1868, Kjøbenhavn, Gyldendal.

Monrad, D.G. (1842), "Om Retten til at udtræde af Statskirken (I Anledning af Baptisterne)" i Flyvende politiske Blade IV, København, Reitzel, 3-23.

Mynster, Jakob Peter (1839), Udkast til en Alterbog og et Kirke-Ritual for Danmark, København, Schultz.

- (1840), Oplysninger angaaende Udkastet til en Alterbog og et Kirke-Ritual for Danmark, København, Gyldendal.

- (1842), Der skal blive een Hjord, een Hyrde. Ordinations-Tale holden den 30. marts 1842 ved Indvielsen af en til Grønland beskikket Missioner, København, Reitzel.

- (1854), Meddelelser om mit Levnet, København, Gyldendal.

Nun, Katalin (2013), Women of the Danish Golden Age. Literature, Theater and the Emancipation of Women, København, Museum Tusculanum.

Raphael, Clara (1851), Tolv Breve, udg. af J.L. Heiberg, Kjøbenhavn, Reitzel.

Rasmussen, Jens (1999), J.P. Mynster. Sjallands biskop 1834-1854. Kampen for en rummelig kirke. Forholdet til N.F.S. Grundtvig og Grundloven, Odense, Odense Universitetsforlag.

Rogerson, J.W. (1992), W.M.L. de Wette. Founder of Modern Biblical Criticism. An Intellectual Biography, Sheffield, Sheffield Academic Press.

Rønning, Frederik (1907-1914), N.F.S. Grundtvig. Et bidrag til skildring af dansk åndsliv i det 19. arrhundrede, bd. 1-4 i 8 dele, København, Schønberg.

Schleiermacher, Friedrich (1831), Der christliche Glaube nach den Grundsätzen der evangelischen Kirche im Zusammenhange dargestellt, bd. 1-2, Berlin, Reimer.

Schreiber, Gerhardt (2009a), "Magnús Eiríksson: An Opponent of Martensen and an Unwelcome Ally of Kierkegaard" i J. Stewart (udg.), Kierkegaard and his Danish Contemporaries (Kierkegaard Research: Sources, Reception and Recources, bd. 7, tome II), Farhham, Ashgate, 49-94.

- (2009b) "Magnús Eiríksson” i Biographisch-Bibliographisches Kirchenlexikon, bd. 1-30, udg. af F.W. Bautz og T. Bautz, Nordhausen, Traugott Bautz Verlag, 1975-2009, bd. 28, sp. 517-33.

- (2012), “'Like a Voice in the Wilderness': Magnús Eiríksson’s Tenacious Critique of Martensen - and Martensens 'Lofty Silence"” i J. Stewart (udg.), Hans Lassen Martensen. Theologian, Philosopher and Social Critic (Danish Golden Age Studies, bd. 6), København, Museum Tusculanum, 155-91. 